Research article

\title{
Modeling areal measures of campsite impacts on the Appalachian National Scenic Trail to enhance ecological sustainability
}

\author{
Johanna R. Arredondo $^{a}$, Jeffrey L. Marion ${ }^{\text {b, }}$, Fletcher P. Meadema ${ }^{a}$, Jeremy F. Wimpey ${ }^{c}$

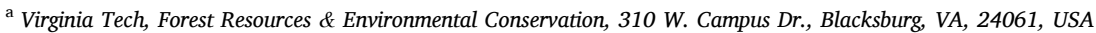 \\ ${ }^{\mathrm{b}}$ U.S. Geological Survey, Virginia Tech Field Station, 304f Cheatham Hall, 310 W. Campus Dr., Blacksburg, VA, 24061, USA \\ ${ }^{\mathrm{c}}$ Applied Trails Research, State College, PA, 16803, USA
}

\section{A R T I C L E I N F O}

\section{Keywords:}

Camping impact

Sustainable camping management

Recreation ecology

Visitor impact management

\begin{abstract}
A B S T R A C T
Campsite impacts in protected natural areas are most effectively minimized by a containment strategy that focuses use on a limited number of sustainable campsites that spatially concentrate camping activities. This research employs spatial autoregressive (SAR) modeling to evaluate the relative influence of use-related, environmental, and managerial factors on two salient measures of campsite impact. Relational analyses examined numerous field-collected and GIS-derived indicators, including several new indicators calculated using highresolution Light Detection and Ranging (LiDAR) topographic data to evaluate the influence of terrain characteristics on the dependent variables.

Chosen variables in the best SAR models explained 35\% and 30\% of the variation in campsite size and area of vegetation loss on campsites. Results identified three key indicators that managers can manipulate to enhance the sustainability of campsites: campsite type, and terrain characteristics relating to landform slope and topographic roughness. Results support indirect management methods that rely on the location, design, construction, and maintenance of campsites, instead of direct regulations that restrict visitation or visitor freedoms. As visitation pressures continue to increase, this knowledge can be applied to select and promote the use of more ecologically sustainable campsites.
\end{abstract}

\section{Introduction}

Most U.S. and international land management agencies operate under dual, competing objectives related to the sustainability of recreational visitation: one to protect the quality of natural resources and one to provide for recreational access and outdoor experiences. Current and increasing visitation to protected natural areas has the potential to negatively impact natural resources and threaten the quality of visitors' experiences. U.S. laws such as the Wilderness Act of 1964, the National Trails System Act of 1968, and the National Forest Management Act of 1976 direct federal agencies to plan for and manage visitor uses that are compatible with agency mandates and can be sustained without unacceptable resource or experiential impacts.

The majority of recreation impacts result from visitors spending time on or near recreation sites (e.g. campsites or day-use sites) or when traveling along trails between these sites. A widely applied impact management strategy for travel-related impacts is to concentrate traffic on a sustainably designed and managed system of formal trails. In the U.
S., land managers have developed designated day-use and overnight facilities in accessible frontcountry settings, but these are less common in remote backcountry or wilderness settings, the subject of this paper. Instead, managers have generally allowed visitors to select and create their own day-use recreation sites or overnight campsites, which are rarely chosen based on sustainability attributes (Cole, 2013; Cole and Parsons, 2013; Marion, 2016; Marion et al., 2018a). In contrast, managers routinely apply knowledge about factors that significantly influence trail degradation to route and design sustainable trails in backcountry and wilderness settings (Marion, 2016; Marion and Wimpey, 2017).

The term sustainability has been used across many environmental disciplines and recently was defined for campsites by Marion et al. (2018a) as: “... one that can accommodate the intended type and amount of use over time without unacceptable levels of expansion, degradation, maintenance, and social crowding or conflict." Recreation ecology studies frequently reveal that an array of use-related, environmental, and managerial factors significantly influence natural resource

\footnotetext{
* Corresponding author.

E-mail address: jmarion@vt.edu (J.L. Marion).
} 
impacts, and that managers can manipulate these factors to minimize impacts while sustaining large and increasing numbers of visitors (Eagleston and Marion, 2017; Marion, 2016; Marion and Farrell, 2002). While the practice of closing undesirable or unsustainable campsites has been adopted in some backcountry and wilderness areas (Cole and Parsons, 2013; Marion et al., 2018a), the practice of actively selecting, designating, or constructing highly sustainable campsites remains rare (Daniels and Marion, 2006; Marion et al., 2018b). Researchers in this study aim to further our understanding of the most influential factors that contribute to limiting resource impacts on campsites and the relative influence of each on areal measures of camping impact.

This paper investigates the relative influence of numerous fieldcollected and Geographic Information System (GIS)-derived variables on the size and area of vegetation loss on backcountry campsites through SAR modeling and analyses of campsite data from a 9\% representative sample of the Appalachian National Scenic Trail. Multivariate analyses of this type have not been previously conducted. Results of this exploratory research are expected to yield important new information able to guide the development of ground- or GIS-based sustainability assessment protocols for application to existing or potential new campsites. Achieving such an objective would provide substantial new management tools and capabilities for accommodating existing and future increases in overnight visitation while minimizing associated environmental impacts. Across the national parks in the U.S., backcountry camping has increased $26 \%$ since 1990 , to more than two million visitors in 2017 (NPS, 2018).

\section{Literature review}

Campsite impacts generally result from trampling or depreciative visitor behavior, and include campsite proliferation, expansion of existing campsites, tree damage and felling, vegetation loss and compositional change, soil exposure and loss, water pollution, and wildlife disturbance (Leung and Marion, 2004; Marion et al., 2016). This study is restricted to resource impacts associated with the areal extent of trampling impacts, including the size and area of vegetation loss on overnight campsites. A common management objective is to minimize aggregate camping impacts through actions that reduce the "footprint" or areal extent of intensive camping impact, in part because smaller sites have less vegetation loss, soil exposure and erosion, or damaged and felled trees (Cole, 1989, 1992; Marion, 2016; Marion and Farrell, 2002; Smith and Newsome, 2002).

Campsite and experimental trampling studies indicate the majority of herbaceous vegetation is lost at initial and low levels of camping activity, with diminishing per capita losses as use increases to moderate and high levels (Cole, 1995; Cole and Monz, 2003; Growcock and Pickering, 2011; Marion et al., 2016). Empirical studies demonstrate this asymptotic or "curvilinear" relationship for most forms of trampling impact, including the trampling and loss of vegetation, the pulverization and loss of organic litter, and soil exposure and loss (Cole and Monz, 2004; Hammitt et al., 2015). The implications of these findings are that managers can reduce trampling damage on campsites with two impact management strategies: 1) employing a dispersal strategy using pristine site camping with visitors camping a single night in highly resistan$t$ /resilient settings that show no previous signs of use; or 2) employing a containment strategy with visitors concentrating their use on sustainable high-use well-established or designated campsites (Cole, 1992; Marion, 2016; Marion et al., 2018a). Dispersed camping is generally most effective in remote or low use areas, while the containment strategy is more effective in moderate to high use areas; supporting management actions include the closure and restoration of less sustainable, unnecessary, and low-use campsites, and visitor education promoting the use of low impact camping practices (Marion, 2016).

Hypothetical campsite models developed by Cole (1992), provide further insight into the relative influence of several factors on three core response variables: percent vegetation loss, area of a campsite, and area of vegetation loss. Cole's models suggest that increasing use can have a substantial effect on areal measures of impact, with peripheral and off-site vegetation disappearing as campsite boundaries expand, though percent measures of vegetation loss remain the same. However, if use increases and camping activities are spatially concentrated, the impacted area remains constant, as trampling impacts are contained within campsite boundaries and percent vegetation loss increases to near maximum levels. A key management objective related to campsite sustainability at a site scale is discovering and implementing actions that limit campsite expansion by promoting the spatial concentration of camping activities (Cole, 1989). Similarly, implications for a landscape scale, where managers seek to minimize aggregate camping impacts at a unit level, suggest a strong focus on actions that limit campsite proliferation (Cole et al., 2008; Leung and Marion, 2004).

The importance of reducing the areal extent of impacts, in comparison to the intensity of localized impact, is also reflected in empirical studies (Cole and Marion, 1988; Cole, 1993; Cole and Ferguson, 2009; Cole et al., 2008; Cole and Hall, 1992). The most widely applied U.S. camping management strategy is unconfined camping, commonly called "dispersed" camping, a strategy that emphasizes visitor freedom to select or create campsites with few restrictions. While some managers have emphasized camping dispersal using this strategy, others have directed visitors to choose only well-established campsites, while restoring unnecessary and less sustainable sites (Marion et al., 2018a). However, monitoring and research studies have consistently revealed that in moderate to high use areas an unconfined camping strategy results in extensive and avoidable camping impacts (Cole, 1982a,b, 2013; Cole and Parsons, 2013; Leung and Marion, 2000a, 2000b, 2004). Marion et al. (2018a) review these studies and describe three commonly observed problems: 1 ) visitors frequently create non-sustainable campsites in flat terrain close to attraction or water features, 2) high-density clusters of exceptionally large campsites with unacceptable levels of resource and social impact develop in popular areas, and 3) over time, site proliferation creates large numbers of unnecessary campsites (i.e., occupancy rates are very low). Thus, an unconfined camping strategy frequently fails to disperse use to levels that prevent lasting impact, nor has it consistently concentrated or contained camping to a limited number of sustainable campsites that remain small over time.

\subsection{Factors that affect campsite size}

A variety of use-related, environmental, and managerial factors have been shown to affect the areal extent of camping impacts (Cole et al., 1987; Marion 2016; Marion et al., 2016). Use-related factors shown to influence the variation in campsite size include amount and type of use, visitor behavior, and group size (Cole and Hall, 1992; Hammitt et al., 2015; Liddle, 1997). Numerous studies have shown that amount of use is most directly related to amount of impact at initial and low levels of use, with lessening per capita effects at moderate to high use levels (Marion et al., 2016). Group sizes are more directly influential on site size as they relate to the number of tents that must be accommodated. Unfortunately, visitor use data, particularly for backcountry and wilderness campsites, are generally unavailable, including for this study. Experimental camping studies such as Cole and Monz (2004) can address this important deficiency, but generally only at low use levels.

The most commonly studied environmental factor related to areal measures of campsite impact has been the influence of vegetation type and morphology, with consistent findings that forested herbaceous cover is neither resistant nor resilient to trampling, i.e., the broad-leafed ground vegetation in forests is quickly removed by camping and is unable to recover quickly (Hammitt et al., 2015; Marion et al., 2016). In sharp contrast, the flexible and narrow leaves of grasses and sedges growing in open sunny settings are highly resistant and resilient, with the ability to re-colonize campsites in forested settings that have lost most of their tree cover (Eagleston and Marion, 2017, 2018). Thus, campsite creation and expansion problems in forested areas are far more 
common than in open grassy settings. Studies that have examined soil types and properties have not shown these factors to significantly influence site size (Hammitt et al., 2015).

A small but growing number of studies have investigated the influence of topography (e.g. Cole and Ferguson, 2009; Cole, 2013; Daniels and Marion, 2006; Eagleston and Marion, 2017; Leung and Marion, 1999; Marion and Farrell, 2002). At Isle Royale National Park, Marion and Farrell (2002) attributed small campsite sizes and aggregate impact to the intentional placement of campsites in sloping terrain, where small "side-hill" campsites were constructed through excavation and fill to create small clusters of tent sites. This practice was applied at Annapolis Rocks, Maryland, cited as the Appalachian Trail's most impacted camping area in 2000, shifting all camping from large visitor-created campsites in flat terrain to new topographically-constrained side-hill campsites, reducing aggregate impact from $4004 \mathrm{~m}^{2}$ to $580 \mathrm{~m}^{2}$ (Daniels and Marion, 2006).

Another study in Great Smoky Mountains National Park employed factor and cluster analyses to reveal that large campsites classified as "Extensively Impacted" were frequently located in flat foot-slope topographic positions (Leung and Marion, 1999). A 32-year campsite impact study in northern Minnesota's Boundary Water Canoe Area Wilderness (BWCAW) sought to predict campsite expansion potential with ratings based on constraints imposed by topography and vegetation density (Eagleston and Marion, 2017). The investigators found topography to be predictive, but the dense woody vegetation was too ephemeral over longer periods of time due to fires, insects, and wind storms. Results suggested that camping expansion and campsite creation/proliferation can be effectively deterred by sloping topography and rockiness, or shorelines and wet soils (Eagleston and Marion, 2017). The influence of other topographic attributes, elevation, distances to amenities, plant community, and ecoregion have received limited research attention and appear to be less influential (Leung and Marion, 1999; Marion and Leung, 1997).

Managerial factors that influence campsite size include the ability of managers to select, construct, or manage sustainable campsites, or to promote low impact behaviors through education or regulations. For example, managers can select or construct campsites in sloping terrain (Daniels and Marion, 2006; Reid and Marion, 2004), manipulate the spatial layout of campsites (Kangas et al., 2007; Marion and Leung, 2004), provide facilities that attract and concentrate use (Marion, 2003; Marion and Farrell, 2002), create campsite borders (Leung and Marion, 2004), maintain sites to enhance durability (Cole, 2013), and close and restore sites (Reid and Marion, 2004; Spildie et al., 1999). Management regulatory actions include quotas to limit amount of use, restrict use type (e.g., prohibiting livestock), or limit group sizes. Similarly, managers can promote low impact educational practices, (e.g., Leave No Trace) that encourage the use of sustainable campsites with durable substrates and avoidance of sensitive locations, promote activity concentration, or the dispersal of use to levels that prevent lasting impact (e. g., dispersed pristine site camping) (D'Antonio et al., 2013; Marion, 2014; Marion and Reid, 2007). Additional reviews of influential factors are provided by Hammitt et al. (2015), Marion (2003, Appendix 2), and Marion (2016).

While the recreation ecology literature includes numerous studies examining univariate and bivariate analyses of factors that influence campsite size and sustainability (Leung and Marion, 2000a, 2000b; Marion, 2016), a comprehensive multiple regression modeling analysis could not be located. Larger multivariate analyses have greater capabilities to model the "relative" influence of numerous factors simultaneously. Two studies have applied multivariate factor and cluster analyses with larger numbers of factors, but their primary purpose was to classify campsites by the types of impact exhibited (Leung and Marion, 1999; Monz and Twardock, 2010). This applied study seeks to identify and clarify information on influential factors that managers can manipulate to minimize salient areal measures of camping impact.

In addition, few recreation ecology campsite studies have incorporated GIS analyses that include LiDAR topographic data and Digital Elevation Models (DEM). LiDAR is a remote sensing method that measures distance to a target based on the time for a pulsed laser light to return. A dense point cloud of $\mathrm{x}, \mathrm{y}$, and $\mathrm{z}$ locations for each return can be filtered by algorithms to extract points that more accurately represent bare earth ground elevations, which can be interpolated into DEMs. LiDAR technologies capture and make available landscape and site-level topographic metrics at a much finer resolution than have been previously available (Brubaker et al., 2013). Further exploration of the capabilities offered by GIS and LiDAR topographic data offer many new opportunities to model the factors that affect areal measures of camping impact.

\section{Study area}

The Appalachian National Scenic Trail (AT) is a $3526 \mathrm{~km}$ continuous footpath stretching from Georgia to Maine and encompassing 101,171 ha (Fig. 1). The AT traverses the Appalachian Mountain range through 14 states, 6 National Park Service units, 8 National Forests, and a suite of more than 80 state and local jurisdictions (National Park Service, 2008). The AT receives an estimated two to three million visitors/year, supporting day hikes, weekend backpacking and camping trips, section-hikes, and thru-hikes of the entire trail in a single year (Appalachian Trail Conservancy, 2018a). AT management responsibilities are shared through a unique collaborative partnership between the National Park Service's Appalachian Trail Park Office (APPA), the Appalachian Trail Conservancy (ATC), federal, state, and local land managers, and 31 volunteer trail clubs (Appalachian Trail Conservancy, 2009).

Camping management along the AT is diverse, with dispersed, established, and designated site camping at approximately 4000 sites ( 5600 as estimated by this study), and camping at 280 shelters spaced approximately $13 \mathrm{~km}$ apart (appalachiantrail.org, National Park Service, 2008). A survey of AT visitors found that $56 \%$ of the overnight visitors stayed in shelters, $12 \%$ camped near shelters, $23 \%$ stayed at established or designated campsites, and $9 \%$ camped elsewhere along the trail (Manning et al., 2000). Camping regulations and guidance vary considerably due to the numerous management agencies involved though land managers and volunteers have adopted consistent low impact outdoor practices advocated by the national Leave No Trace program (Appalachian Trail Conservancy, 2018b,c).

The AT corridor connects a variety of land designations, including federally designated wilderness, backcountry, rural agricultural areas, and accessible frontcountry. The AT traverses five major geologic subprovinces of the Appalachian Mountains, including some of the oldest geologic strata in the world characterized by fold and thrust marine sedimentary rocks, volcanic rocks, and slivers of ancient ocean floor (National Park Service, 2008). The protected corridor includes a wide range of latitudinal, elevational and moisture gradients that support diverse flora and fauna and protect watersheds that provide significant ecosystem services (National Park Service, 2008).

The AT passes through 14 major forest types, including rare alpine and subalpine vegetation communities, spruce-fir, and northern hardwood forests in the North, to hickory, oak and mixed hardwood forests in the South (National Park Service, 2008). While predominantly forested, the AT also traverses grassy balds and treeless high-elevation vegetation communities with elevations ranging from 38 to $2019 \mathrm{~m}$. The AT corridor provides critical habitat for nine federally endangered and threatened species and over 80 globally rare plant community types, including two of the most endangered U.S. ecosystems: red spruce/Fraser fir forest and the Southern Appalachian Mountain bogs (National Parks Conservation Association, 2010). 


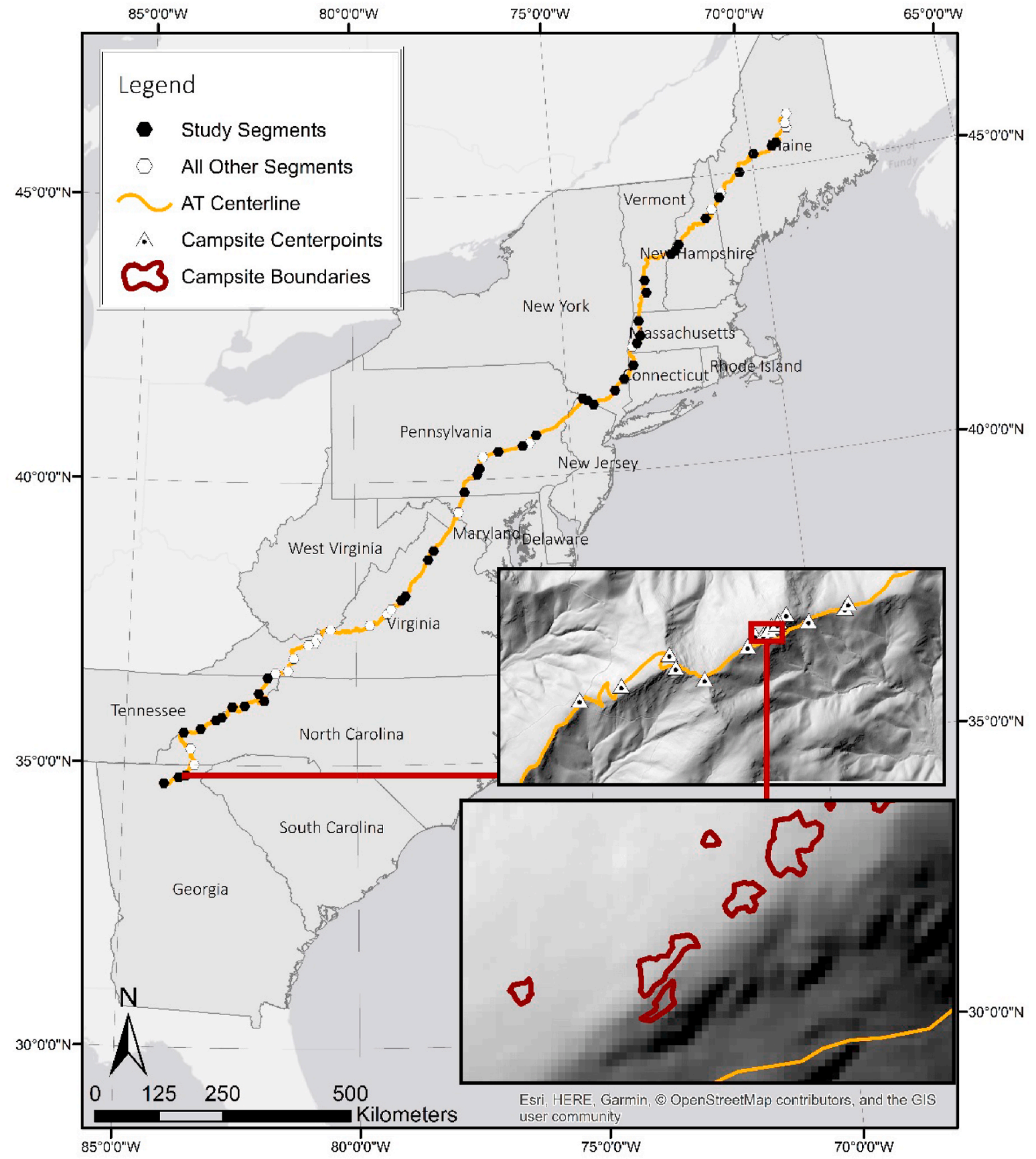

Fig. 1. The $3526 \mathrm{~km}$ Appalachian Trail traverses the Appalachian Mountains from Georgia to Maine. This study sampled $9 \%$ of the AT based on measurements collected within 63 sampled $5 \mathrm{k}$ study segments; though only 42 segments with overlapping LiDAR data and campsites were used in this study (black hexagons). Insets show some of the campsite locations from segment 3 and an enlarged section revealing individual campsite polygons.

\section{Methods}

\subsection{Sample selection}

Along the AT a random, spatially-balanced 9\% representative sample was selected using the Environmental Protection Agency's Generalized Random Tessellation Stratified (GRTS) sample design (Stevens and Olsen, 2004). Spatially balanced designs ensure that sampling is spread evenly to ensure good spatial coverage of the entire survey area (Brown et al., 2015). The AT was divided into 705 5-km segments and 63 were selected using the GRTS sampling algorithm (Fig. 1). During three summers of fieldwork (2015-17) field staff carefully searched each segment within $150 \mathrm{~m}$ of the AT centerline by following all informal (visitor-created) trails to locate and assess all disturbed areas judged to have been created by overnight camping, including in the vicinity of shelters.

\subsection{Field procedures}

Within the 63 study segments field staff located and assessed 504 campsites. Campsite boundaries and center points were recorded using a Trimble GeoXT and boundary polygons were used to compute campsite sizes, similar to D'Antonio et al. (2013). Center points were collected as an average of 50 points, while boundaries were collected as polygons formed by walking the edge of the campsite. To mitigate possible accuracy issues of smaller campsite areas, campsite polygons were visually 
checked for accurate representations of shape and area on the receiver in the field. Very small campsites and campsites for which accurate GPS readings could not be obtained were measured using the geometric figure method (Marion, 1995). Site boundaries were identified by pronounced visually obvious changes in a combination of vegetation cover, vegetation height/disturbance, vegetation composition, and surface organic litter caused from trampling-intensive camping activities (Marion, 1995).

Within each campsite boundary, an ocular estimate of live vegetation groundcover and exposed soil was made based on six cover classes (0-5\%, 6-25\% 26-50\%, 51-75\%, 76-95\%, 96-100\%), with mid-point values recorded. A percentage estimate of vegetation groundcover was also recorded for an adjacent offsite, environmentally similar control area that lacked human disturbance (Marion, 1995).

We sought without success to obtain estimates of campsite use levels from agency and club volunteer staff. Reliable and accurate use data are a perennial problem for campsite studies in wildland settings (Cole, 1986; Cole and Marion, 1988; Eagleston and Marion, 2017). Visitors do not need to obtain permits to hike or camp along most of the AT so there is no practical method for estimating campsite use levels. We tried estimating use levels based on field observable cues, including amount of soil exposure on campsites, which has been shown to be more linearly related to use level (Cole and Fichtler, 1983; Coombs, 1976; Marion, 1984). However, we lack full confidence in these estimates and have omitted them from our analyses.

Other characteristics recorded in the field include campsite type, tree canopy cover, offsite woody vegetation density, offsite topographic roughness, and site expansion potential. Campsite type refers to the following categories: campsite, shelter site, side-hill campsite, and campsites on roads (Fig. 2). Side-hill sites are those located in sloping terrain constructed with cut-and-fill excavations to create small level campsites. Campsites on roads are those created by visitors or trail managers along former (closed) forest dirt roads. Tree canopy cover was estimated using the six groundcover categories as the percentage of the site shaded by the tree canopy when the sun is directly overhead. Offsite woody vegetation density and offsite topographic roughness (ruggedness due to rocks) were recorded in three categories (low, medium, high), referencing the extent to which vegetation density or landscape roughness in immediate offsite areas would constrain campsite expansion. Site expansion potential was rated using three categories (poor, moderate, high), also referencing the extent to which features in immediate offsite areas would constrain campsite expansion, including slope, rockiness, vegetation density, and/or drainage (Eagleston and Marion, 2017). A more comprehensive description of sampling and field assessment protocols is included in Marion et al. (2020a).

\subsection{GIS variables}

GPS data collected in the field were imported, differentially corrected using Trimble's Pathfinder Office software, and converted to shapefiles for editing in ArcMap 10.5.1 software (ESRI, Redlands, CA, USA). Limited editing was necessary to correct horizontal errors, such as moving the campsite polygon to the averaged center point. Professional judgement and campsite photos were used to aid the editing process. When the averaged horizontal error for polygons exceeded $2 \mathrm{~m}$ the campsites were excluded from analyses.

A careful search of online data revealed 13 sources of LiDAR-derived DEM data that were publicly available, providing coverage for 42 of the 63 sampled AT segments. Sources and specifications for LiDAR data can be found in Marion et al. (2020a). Four segment DEMs were interpolated
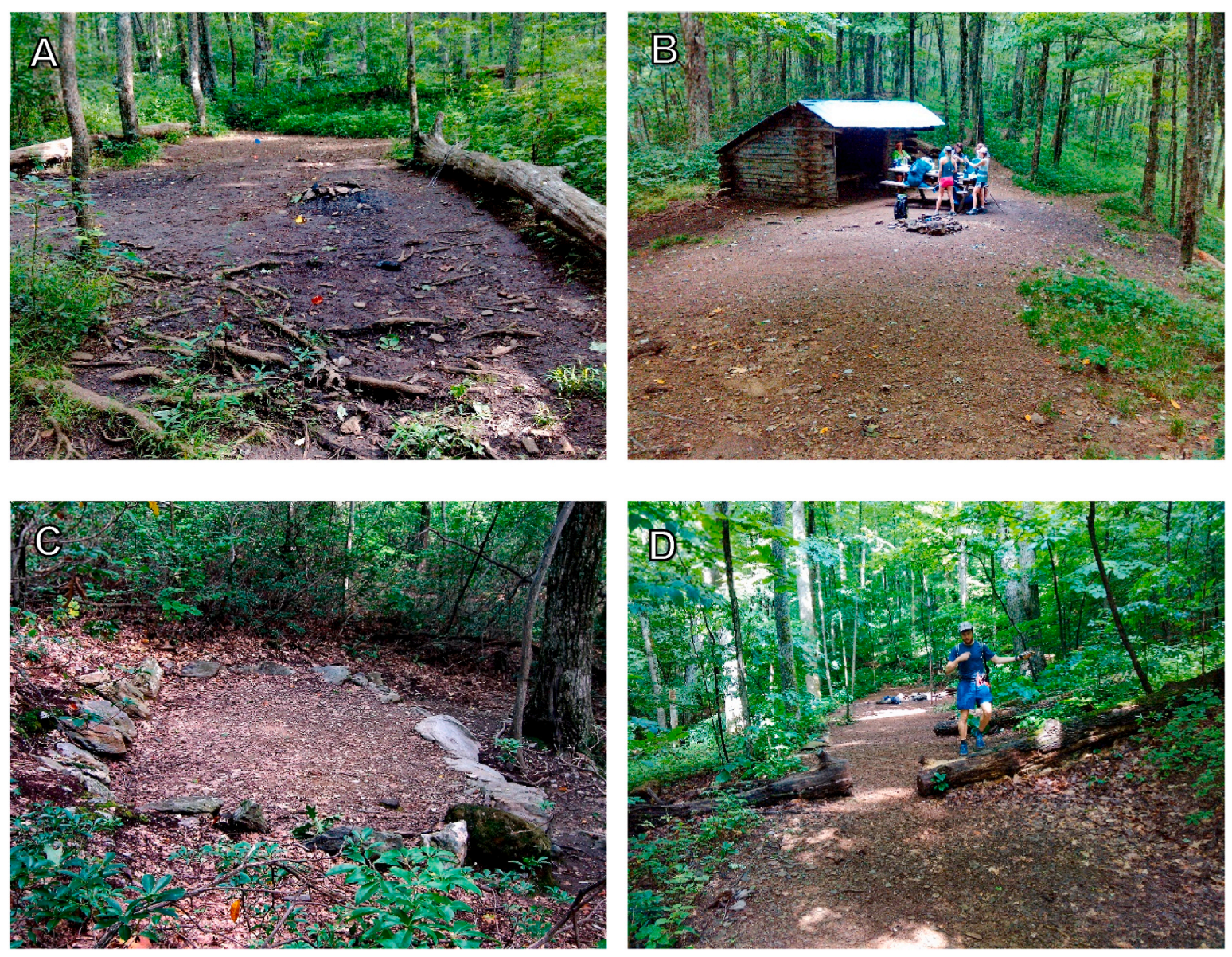

Fig. 2. Photos illustrating four campsite types: A - Campsite, B - Shelter, C - Side-Hill Campsite, and D - Campsite on Road. 
from bare-earth classified points using the inverse distance weighting algorithm in the ArcMap software. Obtaining consistent and identical spatial data across the length of the AT was not possible due to differing collection sensors, vendors, and processing methods. DEM resolutions included 19 study segments at $<1 \mathrm{~m}, 12$ at $1 \mathrm{~m}, 8$ at $2 \mathrm{~m}$, and 3 at $3 \mathrm{~m}$. LiDAR DEM data were considered essential to the regression modeling conducted in this study, which therefore utilized the 42 sampled AT segments with LiDAR data, reducing campsite numbers from 504 to 207.

Terrain characteristics representing variables that could influence campsite expansion were computed in ArcMap 10.5.1 software using the bare earth DEM for each segment. These variables include measurements of topographic slope, curvature, terrain roughness, and topographic position. Percent slope was computed using the Slope tool in the Spatial Analyst Extension in ArcMap 10.5.1. The roughness of the terrain may discourage campsite use and concentrate use to smoother areas. Terrain roughness was calculated using three methods: standard deviation of elevation, standard deviation of slope, and a terrain ruggedness index. Standard deviation of elevation and slope was measured using the Focal Statistics tool in ArcMap over a $5 \mathrm{~m}$ by $5 \mathrm{~m}$ moving window of the elevation and percent slope layers, respectively. The Terrain Ruggedness Index (TRI), created by Riley et al. (1999), is used to characterize terrain heterogeneity and has been applied in other ecological studies on soils, vegetation, and habitat mapping (e.g., Lindsay et al., 2015; Sharma et al., 2015; Tien Bui et al., 2017). Equation (1) was used to compute TRI, where max and min are the largest and smallest values of a specified neighborhood surrounding the cell. Focal statistics was used to compute maximum and minimum values of a $15 \mathrm{~m}$ by $15 \mathrm{~m}$ neighborhood, the approximate size of an average campsite, surrounding a cell.

$T R I=\sqrt{\left|\max ^{2}-\min ^{2}\right|}$

Campsites may differ in size based on their position in the landscape (e.g., valley, mid-slope, ridge). The Topographic Position Index (TPI) was used to represent relative position in the landscape using an algorithm presented by Weiss (2001), by comparing the elevation of a raster cell to the mean elevations of cells surrounding it. Equation (2) was used to compute TPI.

$T P I=\frac{\text { dem }- \text { focalmean }(\text { dem }, \text { annulus }, \text { irad }, \text { orad })}{\text { focalStDev }(\text { dem }, \text { annulus }, \text { irad }, \text { orad })}$ [scalefactor $=$ outer radius in map units, irad $=$ inner radius of annulus in cells, orad $=$ outer radius of annulus in cells].

TPI can be computed at different scales by manipulating the size of annulus, a ring shape with an inner and outer circle, used in analysis. Different scales may give insight into position in the overall landscape vs. position at a smaller scale. Three TPI maps were computed at different scales: one at a large spatial scale using an inner radius of $40 \mathrm{~m}$ and outer radius of $80 \mathrm{~m}$; one at a mid-scale using an inner radius of 20 $\mathrm{m}$ and outer radius of $40 \mathrm{~m}$; and one at a micro-scale with an inner radius of $5 \mathrm{~m}$ and an outer radius of $10 \mathrm{~m}$. TPI breakpoints were reclassified based on values and slope into land position categories defined by Weiss (2001).

The approach developed to characterize the area around a campsite and how it may influence site expansion was exploratory in nature and several different methods were tested. Two types of buffers at different scales, from which statistics could be extracted, were created to characterize the area directly surrounding campsites that may influence the location or potential expansion of campsite boundaries. For the first buffer type, campsite polygons were buffered by $10 \mathrm{~m}, 20 \mathrm{~m}$, and $30 \mathrm{~m}$, and the Erase tool was used to remove the existing campsite footprint from analysis (Fig. 3). A second type of buffer was created under an assumption that campsite boundaries could have expanded to the point where offsite topographic characteristics are constraining further expansion. To explore this, circular polygons of the median campsite size $\left(\sim 152 \mathrm{~m}^{2}\right)$ from our dataset were created and placed on campsite center points. These new median campsites were buffered at $10 \mathrm{~m}, 20 \mathrm{~m}$, and $30 \mathrm{~m}$ with the median campsite footprint erased (Fig. 3). The objective was to examine topographic attributes that encouraged or discouraged further expansion from the median size, resulting in the campsite's current size. The Zonal Statistics tool was used to extract mean and median statistics (where appropriate) from the created raster layers within these buffers.

Slope was additionally split into three slope categories: $0-8 \%$, $9-15 \%,>15 \%$ and the percent of the campsite buffers that contained each of these categories was calculated. The upper slope threshold of $15 \%$ was chosen based on observations by Daniels and Marion (2006), noting that constructed side-hill campsites in $10-15 \%$ sloping terrain were still able to expand slightly.

Distance measurements were calculated as Euclidean distances in ArcMap with the Generate Near Table tool. Distance measurements were

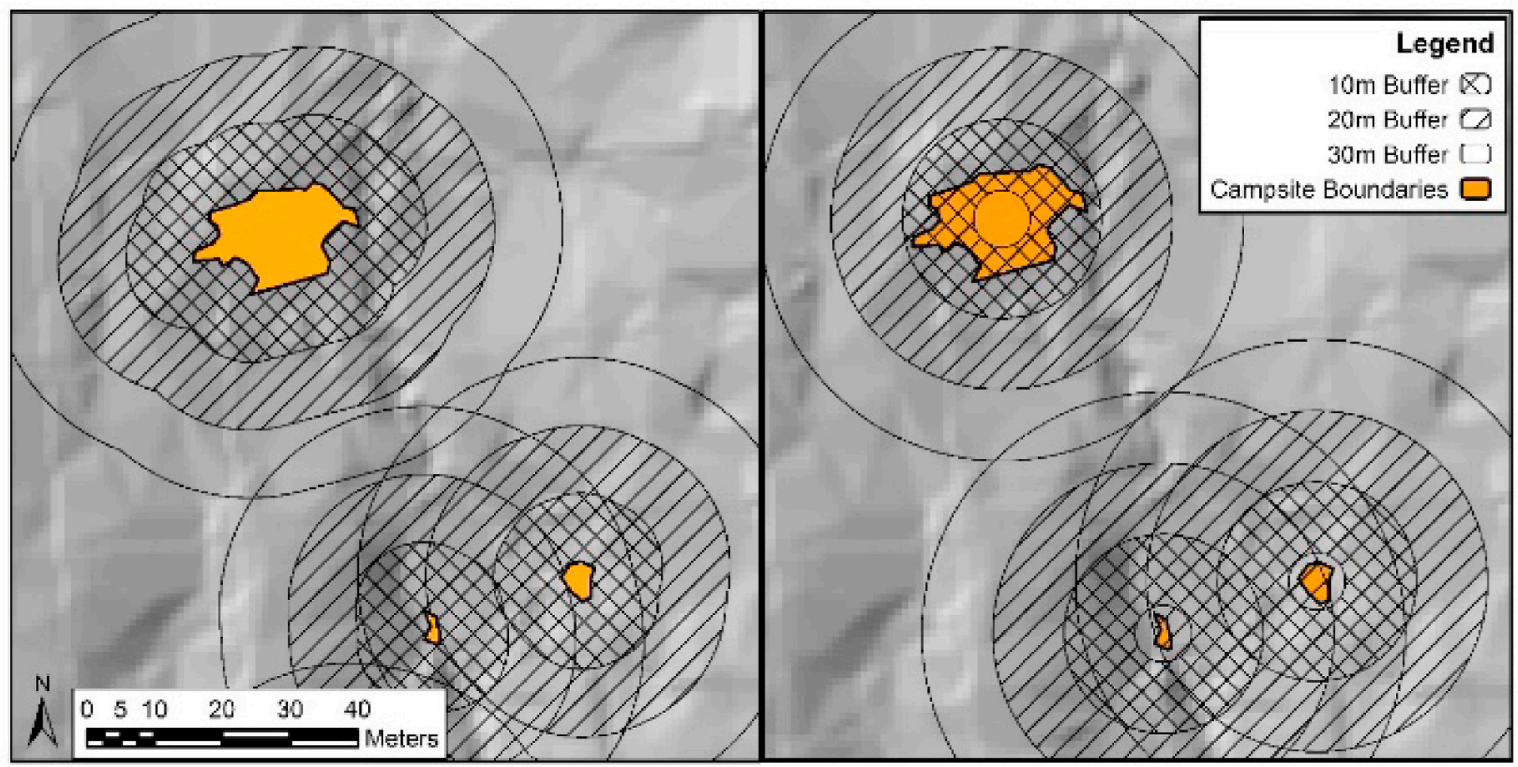

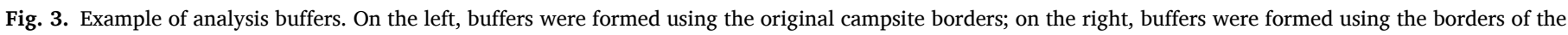

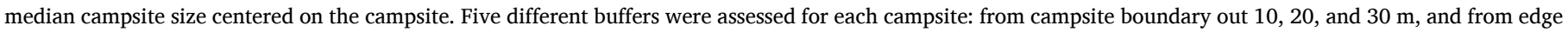
of $10-20$ and $20-30 \mathrm{~m}$. 
calculated from campsites to shelters, privies, water sources, vistas, parking areas, the AT tread, and other campsites. Distances between campsites and these features may influence popularity, and therefore use levels, at specific campsites. The National Land Cover Database (NLCD), a Landsat-based land cover database, provides broad descriptions of the land surface, e.g., classifications such as deciduous forest and developed open space, and was downloaded from the MultiResolution Land Characteristics (MRLC) Consortium (mrlc.gov).

\subsection{Data analyses}

The dependent (response) variables used in regression modeling included two managerially and ecologically important areal measures of camping impact: campsite size and area of vegetation loss (Cole, 1989; Marion, 2016). Campsite areas were calculated using the tool Calculate Geometry in ArcMap. Area of vegetation loss was calculated as the product of absolute vegetation loss and campsite size (Cole, 1989). Campsite size was log transformed and the area of vegetation loss was cube root transformed to satisfy assumptions of normality for regression.

\subsubsection{Choosing the appropriate buffer and summary statistics for terrain variables}

Standard least squares regression using the minimum Bayesian information criterion (BIC) was performed between the dependent variables and variables that were created using alternative buffers and computational methods (e.g., slope surrounding campsites was measured as a mean, median, or percent of a buffer in a certain slope class). Models using the $10 \mathrm{~m}$ buffer around the median campsite sizes had consistently lower BIC values than models using other buffer sizes and actual campsite boundaries. This statistic extraction method was chosen for terrain characteristics generated in GIS and entered into the variable selection process. For slope measurements, the proportion of the $10 \mathrm{~m}$ buffer that is steeply sloped ( $>15 \%$ ) had a lower BIC value than other statistical measures of slope surrounding campsites. This slope measurement was chosen and entered into the variable selection process.

\subsubsection{Building the regression model: choosing key predictors from many candidate variables}

To pare down and identify key predictors from 16 different candidate independent variables the Least Absolute Shrinkage and Selection Operator (LASSO) penalized regression procedure with 5-fold crossverification modeling was used (Tibshirani, 1996). By penalizing the absolute size of the coefficients or constraining the sum of the absolute value of coefficients, LASSO shrinks weak regression coefficients to zero, while retaining the stronger, better performing variables. Variables selected through LASSO were used as starting points for identifying the best model in multiple linear regression.

To avoid overfitting and to achieve a parsimonious model, the regression models were then simplified by removing variables with low significance, i.e., $\mathrm{p}>0.05$ in succession from largest to smallest until only significant coefficients remained.

\subsubsection{Testing for spatial autocorrelation and spatial autoregressive (SAR) modeling}

One assumption of ordinary least squares (OLS) regression is that the error terms are normally distributed and uncorrelated. For spatial data, such as campsites that have a specific location, regression residuals should be checked for spatial dependencies. When spatial autocorrelation exists in the model the estimates can be inaccurate or biased (Anselin, 1988a; Golgher and Voss, 2016). The alternative to OLS regression is spatial autoregressive (SAR) modeling which considers the spatial effects.

Campsite sizes and vegetation loss on campsites near each other can be influenced by similar vegetation types or type and amount of use, in comparison to campsites located further away. To determine if the spatial relationships influence the dependent variable, the OLS regression model residuals were checked for spatial autocorrelation using the Moran's-I test. Two types of spatial dependence can occur, and each require a different type of SAR model. When error terms are correlated across different spatial units, the assumption of uncorrelated error terms in OLS regression is violated and a spatial error model (SEM) is required. When the dependent variable is affected by the independent variables within a spatial unit and neighboring units, the assumption of independent observations in OLS regression is also violated and a spatial lag model (SLM) is required (Golgher and Voss, 2016). Lagrange multiplier tests were performed on the nonspatial models to guide selection of the most appropriate spatial model (Anselin, 1988a, 1988b; Golgher and Voss, 2016).

To carry out SAR modeling spatial weights were created using the Euclidean distance to the center point of each campsite and the inverse distance function with a power of 1 . SAR modeling was then conducted using R statistical software.

\subsubsection{Additional analysis: individual influence of key variables}

To examine the individual influence of key variables, the KruskalWallis rank sum test and the Steel-Dwass method were applied. These non-parametric tests were used due to violation of the normality assumption.

\section{Results}

\subsection{Regression modeling}

The influence of field-measured and GIS-generated independent variables on site size and area of vegetation loss were investigated with SAR modeling. Table 1 presents results from the final regression models.

A Moran's-I test for spatial autocorrelation indicated that a SAR model was needed for both. The Moran's-I test on residuals from the site size nonspatial regression had a p-value of 0.0151 and the vegetation loss nonspatial regression Moran's-I test was 0.0378 . We can conclude that the residuals from both nonspatial regressions are spatially clustered more than expected by chance alone, violating the assumptions for multiple regression and requiring the use of SAR models. Lagrange multiplier tests indicated that a SEM model was appropriate for the site size regression and a SLM model for the area of vegetation loss regression.

The campsite size SEM model can be interpreted as the same as an OLS regression model. Coefficients have been transformed to their original units $\left(\mathrm{m}^{2}\right)$ and are presented in Table 1 . A column representing percent change for one unit change in the independent variable is also included to aid interpretation. The most significant variables in this model are the Shelter campsite type and the proportion of the surrounding area that is steeply sloped. This model predicts that when a campsite type changes from Campsite to Shelter, campsite size is multiplied by 4.1 , or increases by about $309 \%$. Additionally, for every added percentage of the buffer that is steeply sloped, campsite size is multiplied by 0.99 , or decreases by about $0.2 \%$. In other words, all other variables remaining constant, this model predicts that a campsite located in flat terrain will be $127 \mathrm{~m}^{2}$, a campsite surrounded by $50 \%$ steep slopes will be $78 \mathrm{~m}^{2}$, and a campsite $100 \%$ surrounded by steep slopes will be $47 \mathrm{~m}^{2}$.

Micro-topography, as represented by a categorical rugosity variable assessed for surrounding off-site areas, was also included in the campsite size model ( $\mathrm{p}=0.0004$ ) (Table 1$)$. Campsites with substantially uneven terrain or rockiness in offsite areas were significantly smaller than those with less rugose (smooth) substrates (Table 1 ).

The cube root transformation of the area of vegetation loss dependent variable, makes the SLM coefficients hard to specifically interpret, and coefficients cannot be transformed back to their original units. The SLM model can still be generally interpreted. The Shelter campsite type and proportion of buffer that is steep are still highly influential 
Table 1

Final SAR model estimates for the two dependent variables: site size and area of vegetation loss.

\begin{tabular}{|c|c|c|c|c|c|c|}
\hline \multirow[t]{3}{*}{ Variables } & \multirow[t]{3}{*}{ Categories } & \multicolumn{5}{|c|}{ Regression Models } \\
\hline & & \multicolumn{3}{|l|}{$\begin{array}{l}\text { SEM: } \\
\text { Site Size }\left(\mathrm{m}^{2}\right)\end{array}$} & \multicolumn{2}{|l|}{$\begin{array}{l}\text { SLM: } \\
\text { Area of Vegetation Loss }\left(\mathrm{m}^{2}\right)\end{array}$} \\
\hline & & Estimate $\left(\mathrm{m}^{2}\right)$ & Percent change & p-value & Estimate (cube root transformed) & p-value \\
\hline Spatial variable & & Lambda $=1.22$ & - & 0.0561 & Rho $=0.23$ & $0.0121^{\mathrm{a}}$ \\
\hline Constant & & 126.86 & - & $<.0001^{\mathrm{a}}$ & 2.95 & $<.0001^{\mathrm{a}}$ \\
\hline \multirow[t]{4}{*}{ Campsite Type } & Shelter & 4.1 & 309.4 & $<.0001^{\mathrm{a}}$ & 1.71 & $<.0001^{\mathrm{a}}$ \\
\hline & Campsite & - & - & - & - & - \\
\hline & Side-hill & 0.73 & -26.8 & 0.3225 & -0.48 & 0.3688 \\
\hline & Side-hill, Rd. & 1.38 & 37.7 & 0.4695 & 0.35 & 0.6382 \\
\hline Proportion of buffer steeply sloped ( $>15 \%$ ) & & 0.99 & -0.2 & $<.0001^{\mathrm{a}}$ & -0.001 & $0.0150^{\mathrm{a}}$ \\
\hline Tree Cover $(\%)$ & & $\mathrm{n} / \mathrm{a}$ & $\mathrm{n} / \mathrm{a}$ & $\mathrm{n} / \mathrm{a}$ & 0.02 & $0.0012^{\mathrm{a}}$ \\
\hline Distance to Nearest Site (m) & & 0.99 & -0.09 & $0.0028^{\mathrm{a}}$ & -0.002 & $<.0001^{\mathrm{a}}$ \\
\hline \multirow[t]{3}{*}{ Rugosity } & High & 0.46 & -54.2 & $0.0004^{\mathrm{a}}$ & -0.87 & $0.0204^{\mathrm{a}}$ \\
\hline & Medium & 0.78 & -21.6 & 0.1471 & -0.80 & $0.0048^{\mathrm{a}}$ \\
\hline & Low & - & - & - & - & - \\
\hline $\mathbf{R}^{2}$ & & 0.35 & & & 0.30 & \\
\hline
\end{tabular}

a Statistically significant.

variables. The Shelter campsite type has a large positive relationship with area of vegetation loss while increases in steep surrounding slope has a strong negative relationship with vegetation loss. Tree canopy cover is the second most influential variable in the area of vegetation loss model ( $\mathrm{p}=0.0012$ ) (Table 1$)$, with a positive relationship with area of vegetation loss.

Distance to the nearest other campsite is also a significant variable in both the site size model and the area of vegetation loss model (Table 1).

\subsection{Key variables}

\subsubsection{Campsite type}

The Kruskal-Wallis test revealed statistically significant individual effects of campsite types on the mean values for all impact indicators (Table 2). Mean percent vegetation measurements for side-hill sites reveal low vegetation cover and high vegetation loss. However, the Steel-Dwass method for multiple comparisons indicate statistically smaller areal measures of impact for side-hill campsites compared to shelters and campsites; areal means are consistently much lower on sidehill sites and higher on shelter sites compared to other campsite types. Mean percent measures of exposed soil are higher for shelters and sidehill sites compared to campsites. Percent vegetation loss is not significantly different between any campsite types.

\subsubsection{Tree canopy cover}

Vegetation measures, both areal and percent, were significantly related to percent tree canopy cover (Table 2 ). Results show significantly higher percent vegetation cover on campsites with $0-5 \%$ "open" tree canopies compared to campsites with 75-95\% and 95-100\% tree canopy cover. Differences in tree canopy cover did not significantly affect campsite size or percent exposed soil (Table 2).

\subsubsection{Topography: slope and rugosity}

The proportion of area surrounding the campsite that is greater than 15\% slope was split into four categories: $0-25 \%$ of the buffer occupied by sloping terrain, $26-50 \%, 51-75 \%$, and $76-100 \%$. Slope surrounding campsites was significant to differences in campsite size, area of vegetation lost, percent vegetation onsite, percent vegetation loss, and percent exposed soil (Table 2). Campsites with a higher proportion of sloping terrain surrounding the campsite, $51-75 \%$ and $75-100 \%$, are significantly smaller than those where only $0-25 \%$ of the terrain is sloping $\left(96 \mathrm{~m}^{2}\right.$ and $73 \mathrm{~m}^{2}$ vs. $\left.159 \mathrm{~m}^{2}\right)$. Differences in area of vegetation loss were significant only between the lowest and highest categories and differences in area of exposed soil were not significantly different between slope categories. However, these areal measures decrease sequentially as the proportion of area surrounding campsites with sloping terrain increases.

The concentration effect of sloping terrain is apparent in how percent measures of vegetation and exposed soil changed. Percent vegetation cover is significantly lower on campsites with the highest proportion of surrounding sloping terrain, $75-100 \%$, compared to campsites with the lowest, $0-25 \%$. Percent vegetation loss is highest on campsites in the most sloping terrain, however this is only significantly different than campsites with $26-50 \%$ surrounding sloping terrain. Percent exposed soil is not significantly different across surrounding sloping terrain categories, though campsites with $75-100 \%$ sloping terrain have the highest mean percent exposed soil (45\%).

Micro-topography, as represented by a ground-based rugosity categorical rating, also significantly influenced the mean values for four impact indicators (Table 2). Though somewhat rare ( $\mathrm{N}=25$ out of 263 ), campsites with high rugosity ratings for offsite areas were three times smaller than those with low rugosity and had a quarter of the area of vegetation loss (Table 2). Of note, the influence of offsite rugosity on area of exposed soil was the most significant of any factor evaluated, with mean area of exposed soil twelve times less for campsites with high offsite rugosity ratings compared to those with low ratings (Table 2).

\section{Discussion}

Often understaffed and underfunded, protected natural area managers have universally cited the need to increase the sustainability of their recreational infrastructure to protect natural conditions that support high-quality recreational experiences (Leung et al., 2018). This study aimed at enhancing an understanding of factors that influence the ecological sustainability of campsites. Extensive SAR modeling indicated five variables that significantly explain variation in the areal extent of campsite impacts that managers can act upon: campsite type, offsite slope, tree canopy cover, distance to other sites, and rugosity.

\subsection{The influence of topography}

Regression modeling findings for offsite terrain, campsite type, and rugosity provide clear guidance that managers can use macro- and micro-topography to effectively constrain a campsite's ability to expand. This is similar to trails, where steep slopes adjacent to side-hill trails act to concentrate traffic on a narrow tread, while rugose tread substrates act to widen treads when trail users shift laterally to avoid rocks and roots in search of smoother surfaces (Wimpey and Marion, 2010). Perhaps the most important finding of this study is that campsites located in sloping terrain will spatially concentrate camping activities 
on the available flat terrain, effectively constraining site expansion when offsite areas are sufficiently steep. The most significant campsite size predictor yielded by our modeling was the proportion of the $10 \mathrm{~m}$ median campsite size buffer occupied by steep slopes $(>15 \%)$. The implication of this finding is that spatial concentration of camping activities is highest when a campsite is completely surrounded by steep terrain (Table 2). These sites could be termed "naturally-occurring" sidehill campsites.

Our regression modeling and supporting trail widening results (Wimpey and Marion, 2010) also demonstrate the significant influence of micro-topography, which we term rugosity, in constraining campsite size expansion. Topographic roughness from excessive rock, roots, or uneven ground sufficient to deter tenting also spatially concentrates camping activities. For example, the management strategy of "iceberging" rocks is a traditional practice of partially burying large rocks to increase topographic roughness for the purpose of closing a campsite or constraining activity to a reduced portion of a campsite (Marion, 2003; Marion et al., 2020b). This practice is impractical in large flat areas as it may merely move camping impact to adjacent flat areas. Unfortunately our exploratory analyses in this study revealed that GIS micro-topography measurements using 1-3 m DEM data were apparently insufficiently sensitive measures of rugosity (Brubaker et al., 2013), but our field-assessed categorical measure showed greater promise. Further research on this attribute is recommended as more accurate LiDAR data become available and new processing techniques are developed.

Other studies described in the literature review have acknowledged the possible influence of topography in constraining campsite expansion through expansion potential ratings and analysis of topographic position. For example, Shenandoah National Park's successful conversion to established site camping is attributed in part by park staff shifting camping to a subset of existing campsites located in areas with low expansion potential, as characterized by topographic limitations, rockiness, and/or dense woody vegetation (Reid and Marion, 2004). The specific significance of offsite topography in achieving greater spatial concentration of camping activity has only been mentioned in prior studies (Marion and Farrell, 2002) and its efficacy has only been empirically demonstrated in the context of a single study (Daniels and Marion, 2006). No prior studies have used multivariate analyses or reported the statistical significance regarding the influence of topography that we obtained. We attribute our findings primarily to the greater accuracy provided by employing GIS analyses with LiDAR-generated topography data.

For campsite type, consistent with previous studies, our results find that constructed side-hill campsites resist expansion pressures and are an effective management tool for reducing areal measures of campsite impact (Daniels and Marion, 2006; Marion and Farrell, 2002). Shifting use to distinct "small-footprint" campsites with clear topographically-defined boundaries permanently constrains expansion and prevents the formation of unacceptably large mega-sites. Side-hill campsites situated along old forest roads were less effective in constraining the expansion that could still occur in two directions along the road corridor (Tables 1 and 2); managers could place large logs or rocks to constrain site expansion and increase the efficacy of this practice.

Small naturally-occurring or constructed side-hill campsites also effectively limit other forms of camping impact, such as the number of fire sites, damaged or felled trees, and soil loss. In comparison to normal or large campsites, side-hill sites have exceptionally few onsite or adjacent trees that managers may need to survey and remove as hazardous trees. To enhance experiential qualities, reducing crowding, conflicts, and noise, managers can physically separate side-hill sites (e. g., >70 m apart) (Daniels and Marion, 2006; Marion et al., 2020b).

An important advantage of relying on topography to spatially concentrate camping activities and constrain campsite expansion is that once visitors are on the site they are simply interacting with the natural environment, which effectively compels their behaviors. Visitors simply cannot erect a comfortable tent in sloping, rocky, or uneven terrain. This is viewed as more natural and effective than compelling similar behaviors through regulations (e.g., visitors must camp within $6 \mathrm{~m}$ of a fixed camping post or fire ring) (Marion et al., 2020b). Similarly, a reliance on education and low impact practices (e.g., please camp in the already barren central core campsite areas) is only effective when visitors are fully aware of and compliant with such voluntary practices (Marion, 2014; Marion and Reid, 2007).

Table 2

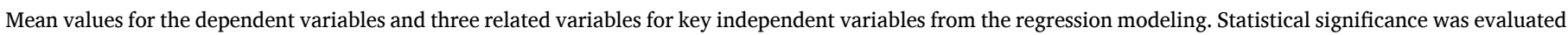
with Kruskal-Wallis Chi-square tests and the Steel-Dwass method for multiple comparisons.

\begin{tabular}{|c|c|c|c|c|c|c|c|c|c|c|c|c|}
\hline \multirow{2}{*}{$\begin{array}{l}\text { Variables } \\
\text { Campsite Type }\end{array}$} & \multirow{2}{*}{$\begin{array}{l}\text { Categories } \\
\text { Campsite }\end{array}$} & \multirow{2}{*}{$\begin{array}{l}\mathrm{N} \\
171\end{array}$} & \multicolumn{2}{|c|}{ Site Size $\left(\mathrm{m}^{2}\right)$} & \multicolumn{2}{|c|}{ Area of Vegetation Loss $\left(\mathrm{m}^{2}\right)$} & \multicolumn{2}{|c|}{ Area of Exposed soil $\left(\mathrm{m}^{2}\right)$} & \multicolumn{2}{|c|}{ Vegetation Cover (\%) } & \multicolumn{2}{|c|}{ Exposed Soil (\%) } \\
\hline & & & $105^{\mathrm{a}}$ & $\mathrm{A}^{\mathrm{b}}$ & 57 & A & 38 & A & 26 & $\mathrm{~A}$ & 30 & $\mathrm{~A}$ \\
\hline & Shelter & 19 & 275 & B & 160 & B & 156 & B & 22 & A & 50 & B \\
\hline & SHC & 12 & 34 & $\mathrm{C}$ & 16 & A & 11 & A & 5 & B & 49 & A B \\
\hline & CR & 5 & 102 & A B C & 73 & A B & 42 & A B & 8 & A B & 45 & A B \\
\hline & \multicolumn{2}{|c|}{$\begin{array}{l}\text { Chi-square/p- } \\
\text { value }\end{array}$} & \multicolumn{2}{|c|}{$28.4 /<.001$} & \multicolumn{2}{|c|}{$13.7 / 0.003$} & \multicolumn{2}{|c|}{$20.5 /<.001$} & \multicolumn{2}{|c|}{$14.2 / 0.003$} & \multicolumn{2}{|c|}{$12.7 / 0.005$} \\
\hline \multirow[t]{7}{*}{ Tree Cover } & $0-5 \%$ & 11 & 92 & A & 7 & A & 27 & A & 58 & A & 27 & A \\
\hline & $6-25 \%$ & 12 & 137 & A & 72 & A B & 55 & A & 34 & A B & 29 & A \\
\hline & $25-50 \%$ & 12 & 163 & A & 98 & A B & 42 & A & 32 & A B & 20 & $\mathrm{~A}$ \\
\hline & $50-75 \%$ & 28 & 130 & A & 69 & B & 53 & A & 28 & A B & 23 & A \\
\hline & $75-95 \%$ & 110 & 120 & A & 70 & $\mathrm{~B}$ & 52 & A & 18 & $\mathrm{~B}$ & 39 & A \\
\hline & $95-100 \%$ & 34 & 75 & A & 46 & $\mathrm{~B}$ & 32 & A & 20 & B & 28 & $\mathrm{~A}$ \\
\hline & \multicolumn{2}{|c|}{$\begin{array}{l}\text { Chi-square/p- } \\
\text { value }\end{array}$} & \multicolumn{2}{|c|}{$6.4 / 0.272$} & \multicolumn{2}{|c|}{$23.7 /<.001$} & \multicolumn{2}{|c|}{$7.8 / 0.165$} & \multicolumn{2}{|c|}{$25.6 /<.001$} & \multicolumn{2}{|c|}{$10.2 / 0.069$} \\
\hline \multirow[t]{5}{*}{ Proportion of Buffer $>15 \%$} & $0-25 \%$ & 73 & 159 & A & 85 & A & 61 & A & 27 & A & 30 & A \\
\hline & $26-50 \%$ & 45 & 109 & A B & 53 & A B & 34 & $\mathrm{~A}$ & 28 & A & 26 & A \\
\hline & $51-75 \%$ & 43 & 96 & B & 56 & A B & 45 & A & 25 & A & 32 & A \\
\hline & $76-100 \%$ & 46 & 73 & $\mathrm{~B}$ & 51 & B & 40 & A & 14 & B & 45 & A \\
\hline & \multicolumn{2}{|c|}{$\begin{array}{l}\text { Chi-square/p- } \\
\text { value }\end{array}$} & \multicolumn{2}{|c|}{$21.6 /<.001$} & \multicolumn{2}{|c|}{$13.2 / 0.004$} & \multicolumn{2}{|c|}{$3.2 / 0.360$} & \multicolumn{2}{|c|}{$12.1 / 0.007$} & \multicolumn{2}{|c|}{$8.0 / 0.046$} \\
\hline \multirow[t]{4}{*}{ Rugosity } & Low & 133 & 135 & A & 79 & $\mathrm{~A}$ & 60 & $\mathrm{~A}$ & 60 & A & 40 & A \\
\hline & Medium & 49 & 103 & A & 47 & B & 34 & B & 46 & A & 24 & B \\
\hline & High & 25 & 46 & $\mathrm{~B}$ & 20 & $\mathrm{~B}$ & 5 & $\mathrm{C}$ & 50 & A & 15 & B \\
\hline & \multicolumn{2}{|c|}{$\begin{array}{l}\text { Chi-square/p- } \\
\text { value }\end{array}$} & \multicolumn{2}{|c|}{$17.5 /<.001$} & \multicolumn{2}{|c|}{$24.1 /<.001$} & 33.2 & .001 & 4.9 & .087 & 25. & $<.001$ \\
\hline
\end{tabular}

\footnotetext{
${ }^{\text {a }}$ Numbers presented are means.

b Means that do not share the same letter are significantly different.
} 


\subsection{The influence of structures}

While our results suggest that shelter sites have the largest size, area of vegetation loss, and soil exposure (Table 2), this finding is misleading because it reflects the extensive tent camping areas located in the immediate vicinity of AT shelters. In this study field staff measured the most connected and proximate disturbed areas around a shelter as the shelter site, and prescribed all associated but separate and more distant disturbed areas as campsites. AT shelters are situated at permanent water sources and their inclusion in guidebooks and maps makes them exceptionally popular camping destinations. Shelter capacities are routinely exceeded so some tent camping represents overflow use, while other backpackers simply choose to camp near shelters. Based on a 1999 visitor survey, about $43 \%$ of non-thru hiking campers use shelters and $59 \%$ of thru-hikers use shelters, with an additional $12 \%$ of non-thru hikers and $14 \%$ of thru-hikers camping in areas around shelters (Manning et al., 2000). Relocating shelters to areas that spatially concentrate camping activities could be key to limiting areal impacts associated with nearby tent camping (Marion et al., 2020b).

Though rarely investigated, camping shelters and huts excel in spatially concentrating camping activities to the structure's small footprint (Marion and Leung, 1997). A study of camping impacts at Great Smoky Mountains National Park found that AT shelters accommodated $37 \%$ of the backcountry overnight visitation while including only $10 \%$ of the total area of backcountry camping disturbance (Marion and Leung, 1997). This finding is even more compelling given that their data were also confounded by the inclusion of shelter-associated tent camping areas.

Our sample included an insufficient number of constructed wooden camping platforms with decking or wooden and rock tent pads to analyze, but other studies have demonstrated their efficacy, including in flat terrain. Dixon and Hawes (2015) describe how the construction of camping platforms in the alpine zone of the Arthur Range of Tasmania "successfully focused camping pressure and so constrained or limited impacts." Similarly, a longitudinal study of the popular Overland Track in Tasmania by Dixon (2017) found improved conditions at locations where wooden camping platforms had been installed, with track rangers reporting a greater concentration of camping use after the structures were installed. While similar wooden camping platforms have been constructed in the New England states, we highlight the advantages of wood or rock bordered tent pads that allow tents to be staked in soil (Fig. 4).

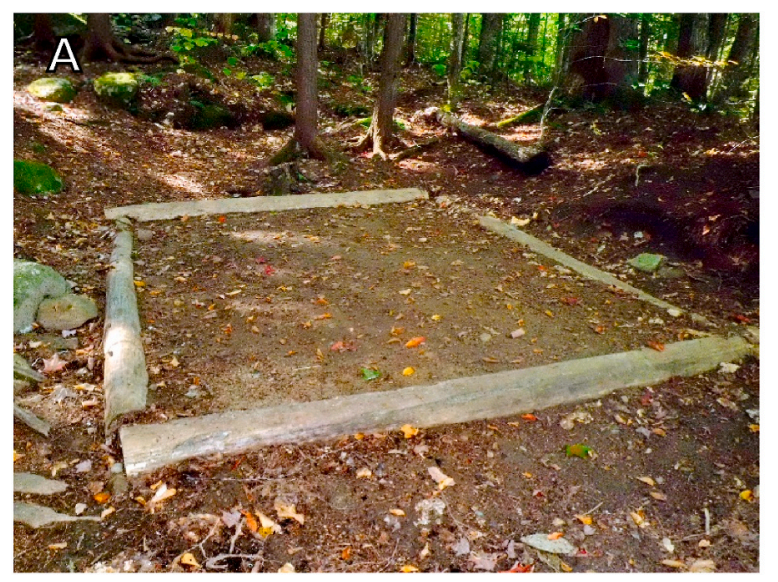

\subsection{The influence of canopy cover}

Regression modeling also revealed a positive and significant relationship between area of vegetation loss on campsites and their tree canopy cover, though data presented in Table 2 reveal a more complex relationship. Sunny campsites with tree cover $<5 \%$ have a mean area of vegetation loss of $7 \mathrm{~m}^{2}$ and mean vegetation ground cover of $58 \%$ (Table 2). Campsites with intermediate tree cover of $25-50 \%$ experience the greatest area of vegetation loss, $98 \mathrm{~m}^{2}$, with mean vegetation cover of $32 \%$. The most shaded campsites with tree cover $>95 \%$ have lost vegetation cover over $46 \mathrm{~m}^{2}$ and have mean vegetation cover of only $20 \%$ (Table 2). These relationships can be explained by the differential variability in the trampling resistance and resilience (ability to recover) of grasses vs. broad-leaved herbs. Experimental trampling studies consistently reveal that grasses and sedges are highly resistant and resilient to trampling in sunny meadows and somewhat less so in open forests; however, they are intolerant of shade and provide little cover under full tree canopies (Cole, 1995; Hill and Pickering, 2009). In contrast, herbs, which have low resistance and resilience to trampling, reach their greatest cover in forests with $25-50 \%$ canopy cover and decline to limited cover under the dense forest canopies.

The implications of these relationships are that grassy meadows and open forests provide sustainable locations for dispersed pristine site camping or for locating established or designated campsites (Fig. 5A). Resistant and resilient grasses resist campsite formation at low use levels and resist or rapidly recover from infrequent activities that expand site boundaries on moderate to high use sites (Marion et al., 2020b). An experimental camping study by Cole and Monz (2003) in the Wind River Mountains of Wyoming found that meadow campsites resisted trampling damage and recovered significantly faster than identical camping activity in settings with forest canopies. Similarly, Eagleston and Marion (2017) reported that tree loss over 32 years on BWCAW campsites resulted in increased sunlight and significant increases in the percent and areal extent of vegetation cover, primarily trampling-resistant grasses, which significantly reduced measures of exposed soil (similar to that depicted in Fig. 5B). Forests with particularly dense canopies can also make good locations for dispersed and established/designated site camping because they have very limited vegetative groundcover that can be lost (though organic litter is lost on well-used sites).

Forested campsites that lose most of their trees and are colonized largely by grasses are ecologically and aesthetically different than the original landscape, "unnatural" changes that could reduce a visitor's perception of wilderness and wilderness character (Eagleston and Marion, 2017, 2018). Shifting camping to more open forests and meadows could alleviate these concerns and reduce safety threats to visitors from

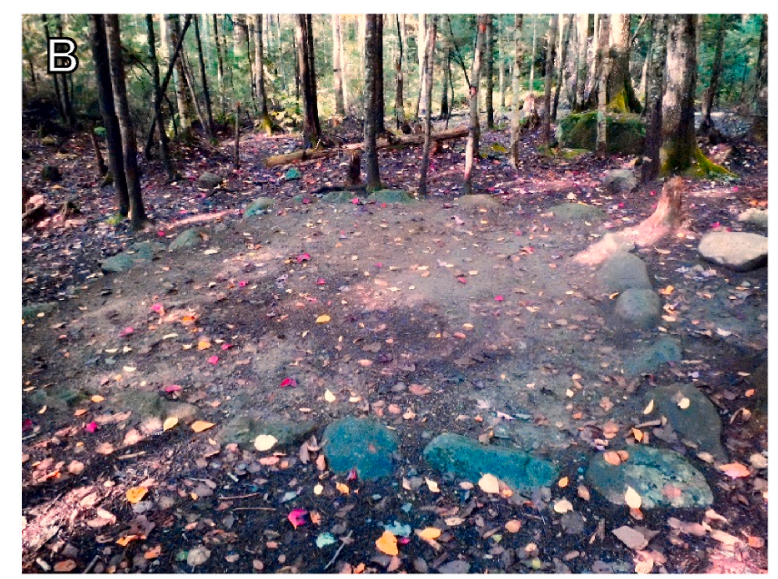

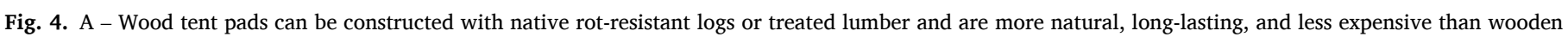

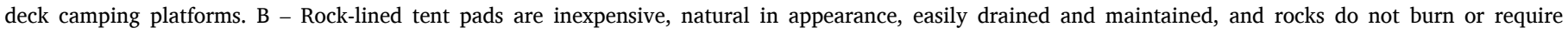
replacement. 

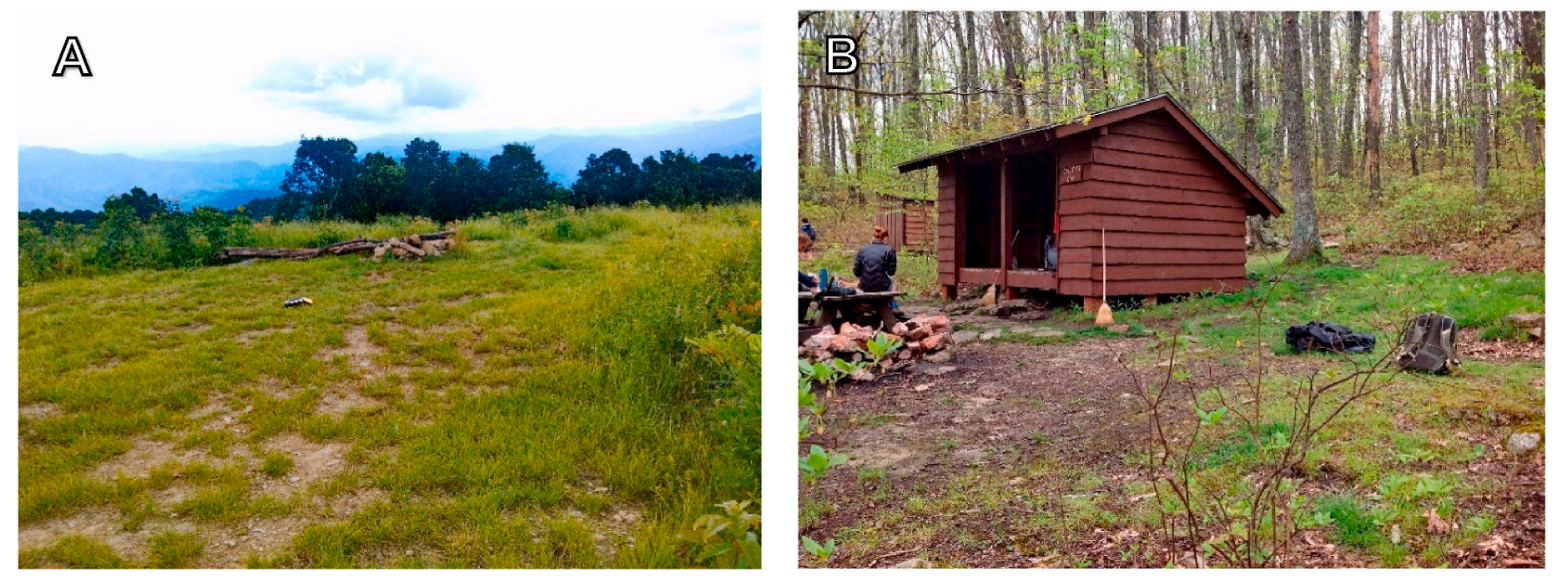

Fig. 5. A - Grasses and sedges in meadows are highly resistant and resilient to trampling damage. This high use site still has $90 \%$ of its vegetation cover, though its reduced height clearly reveals the effects of intensive trampling. B-In forested settings campsites lose trees without replacement over time, an "impact" that allows subsequent colonization by shade-intolerant grasses that increase campsite sustainability. (For interpretation of the references to colour in this figure legend, the reader is referred to the Web version of this article.)

camping near hazardous or dead trees.

\subsection{The influence of other variables}

As mentioned previously, other management strategies have been successful in reducing campsite impacts. This study was not able to evaluate the effect of several practices because they did not appear or there were not enough occurrences within the random sample. An adapted table (Table 3) from Marion and Farrell (2002) summarizes the actions found in this and other studies. Marion et al. (2020b) provide perhaps the most comprehensive review and description of sustainable camping Best Management Practices (BMP's) highlighted in this paper and Table 3.

As noted in the literature review, the campsite use-impact relationship suggests that aggregate camping impact could be substantially reduced by either employing a dispersal strategy and pristine site camping in low use areas, or a containment strategy with established or designated site camping in moderate to high use areas (Leung and Marion, 2004; Marion 2016). Both strategies rely heavily on the ability to select sustainable sites that can accommodate camping activity with low per capita resource impact. Unfortunately, AT managers and volunteers have historically allowed unregulated camping along much of the AT, though they have created approximately 726 side-hill campsites since 2000 and have begun more intensive camping management in Georgia and several other areas (Marion et al., 2020a,b).

This study was unable to investigate the influence of amount of use or the possible effect of limiting use on areal measures of campsite impact. We suspect that the regression modeling inclusion of "distance to nearest site" (Tables 1 and 2) is likely a proxy for amount of use, with higher use associated with large dense clusters of campsites that have smaller intersite distances, often proximate to AT shelters. Seeking to reduce use levels to a point where campsites have substantially reduced size and impact may be impractical and unachievable given the high and increasing popularity of the AT, lack of a permitting mechanism to implement rationing, and the preponderance of recreation ecology research revealing weak use/impact relationships at moderate to high levels of campsite use (Cole, 1982a; Eagleston and Marion, 2017; Marion, 2016; Marion et al., 2016). These studies have consistently shown that amount of use is strongly correlated with amount of camping impact only at initial and low levels of use. Numerous studies have found that beyond moderate use levels, additional use results in diminishing amounts of vegetation and soil impact, including relatively small increases in areal measures of disturbance at the site level.

These empirical findings are supported and explained by Cole's
Table 3

Management actions to reduce camping impacts, adapted from Marion and Farrell (2002).

\begin{tabular}{|c|c|}
\hline Action & Impact Reduction Effect \\
\hline Established or designated site camping & $\begin{array}{l}\text { Implements a containment strategy to } \\
\text { concentrate impact on a limited number } \\
\text { of resistant sites }\end{array}$ \\
\hline Dispersed pristine site camping & $\begin{array}{l}\text { Reduces camping use to levels that } \\
\text { prevent lasting impact. }\end{array}$ \\
\hline Ration/limit use & $\begin{array}{l}\text { Reduces site numbers, particularly if peak } \\
\text { use is restricted. }\end{array}$ \\
\hline $\begin{array}{l}\text { Limit on site numbers to achieve high } \\
\text { site occupancy rates }\end{array}$ & $\begin{array}{l}\text { Reduces site numbers and area of } \\
\text { camping disturbance to the minimum } \\
\text { necessary }\end{array}$ \\
\hline Group size limits & $\begin{array}{l}\text { Minimizes site sizes by limiting tent } \\
\text { numbers }\end{array}$ \\
\hline $\begin{array}{l}\text { Placement of campsites in sloping } \\
\text { terrain, including naturally occurring } \\
\text { or constructed "side-hill" campsites }\end{array}$ & $\begin{array}{l}\text { Enlists topography in promoting activity } \\
\text { concentration to intended use areas }\end{array}$ \\
\hline $\begin{array}{l}\text { Placement of campsites in areas with } \\
\text { substantial offsite rockiness }\end{array}$ & $\begin{array}{l}\text { Improves activity concentration within } \\
\text { site borders }\end{array}$ \\
\hline $\begin{array}{l}\text { Location of campsites in open forests or } \\
\text { meadows }\end{array}$ & $\begin{array}{l}\text { Places campsites on resistant and resilient } \\
\text { grasses and sedges }\end{array}$ \\
\hline $\begin{array}{l}\text { Placement of trails away from undesired } \\
\text { camping locations (e.g. large flat } \\
\text { areas near water) }\end{array}$ & $\begin{array}{l}\text { Reduces likelihood of campsites forming } \\
\text { in undesirable locations }\end{array}$ \\
\hline $\begin{array}{l}\text { Construction and maintenance of } \\
\text { improved tenting sites }\end{array}$ & $\begin{array}{l}\text { Improves activity concentration by } \\
\text { attracting visitors to the intended use } \\
\text { areas }\end{array}$ \\
\hline $\begin{array}{l}\text { Facilities (e.g., shelters, anchored picnic } \\
\text { tables) }\end{array}$ & Attracts and concentrates use \\
\hline $\begin{array}{l}\text { Site maintenance that ruins offsite areas } \\
\text { that receive use }\end{array}$ & $\begin{array}{l}\text { Improves activity concentration and } \\
\text { discourages site expansion }\end{array}$ \\
\hline $\begin{array}{l}\text { Educational messages that encourage } \\
\text { use of core areas }\end{array}$ & Improves activity concentration \\
\hline $\begin{array}{l}\text { Clustering of campsites with a minimum } \\
\text { specified inter-site distance }\end{array}$ & $\begin{array}{l}\text { Limits wildlife habitat fragmentation } \\
\text { while enhancing experiential conditions }\end{array}$ \\
\hline Campsite borders of rocks or logs & $\begin{array}{l}\text { More clearly defines intended campsite } \\
\text { borders }\end{array}$ \\
\hline $\begin{array}{l}\text { Anchored fire rings or placement of } \\
\text { large flat "kitchen" rocks for stove use }\end{array}$ & $\begin{array}{l}\text { Attracts and concentrates cooking } \\
\text { activity at a single site location }\end{array}$ \\
\hline $\begin{array}{l}\text { Provision of food storage boxes or } \\
\text { cables }\end{array}$ & $\begin{array}{l}\text { Enhances safe food, trash, and smellable } \\
\text { storage; protects trees from rope damage }\end{array}$ \\
\hline
\end{tabular}

(1992) hypothetical campsite impact modeling, which attributes this finding to the natural tendency for activity concentration to increase as campsites become more heavily used and impacted. His modeling indicates that the most effective actions managers can apply to reduce impact in popular high use camping areas are those that increase the spatial concentration of camping activity, like the installation of 
camping structures in flat terrain (e.g., anchored fire and tenting sites), or by shifting use to locations where topography and/or rugosity constrain site expansion.

Two important use-related exceptions include large numbers of groups camping in an area at one time, and large group sizes. First, large numbers of groups camping, such as created by the substantial "bubble" of AT thru-hikers each year, disproportionately contribute to campsite proliferation and site expansion problems as they move northward. This extended annual "peak use" event causes chronic site proliferation problems that are creating mega-clusters of campsites around shelters and water sources, and expansion of existing campsites that may merge with proximate sites to form extremely large mega-sites (Marion et al., 2020a). Second, larger organized groups and loosely affiliated "groups" of thru-hikers that are unwilling to split and camp separately can significantly expand typical campsites. Unfortunately, once new campsites are formed or existing campsites are expanded, even limited subsequent camping use by any group is sufficient to prevent recovery of the new sites or expanded areas. Thus, heavy peak use camping activity commonly results in both site proliferation and expansion over time, unless factors promoting the spatial concentration of camping activities are present.

Our data illustrate these twin problems. From our representative $9 \%$ sample, the median AT campsite size is $50 \mathrm{~m}^{2}(\mathrm{n}=504)$. Even a large group of 12 with 6 tents could comfortably use a campsite of about 60 $\mathrm{m}^{2}$, assuming $4 \mathrm{~m}^{2}$ tent sites, a $6 \mathrm{~m}^{2}$ cooking area, and another $30 \mathrm{~m}^{2}$ allowing for spacing between tents. However, our data reveal that excessive campsite proliferation and expansion at many popular AT overnight locations in flat terrain has led to the creation of 79 mega-sites ranging in size from 200 to $774 \mathrm{~m}^{2}$, a substantial $16 \%$ of all sites. The scientific literature and our observations and discussions with various representatives of the AT community point to the large annual bubble of thru-hikers and youth-serving organizations like camps, colleges, scouting, and churches as the chief causes of these large numbers of mega-sites (Marion et al., 2020a,b).

Moving a trail or locating new trails away from accessible and visible flat areas could reduce use to unsustainable sites or prevent the creation of sites in a less sustainable area. This management technique was successfully applied in Arkansas's Caney Creek Wilderness by moving 5 $\mathrm{km}$ of trail up a side-slope, effectively hiding a number of highlyimpacted streamside campsites (Cole and Ferguson, 2009). This technique is supported by previous research indicating that backpackers typically do not travel very far off trail to camp; a survey of campsites performed by Leung and Marion (2000a, 2000b) in Virginia's Jefferson National Forest Wilderness areas found relatively few visitors practiced dispersed camping. Most campsites surveyed were found within sight of the trail and only 20 of 110 sites (18\%) were more than $61 \mathrm{~m}$ away from formal trails.

\subsection{Social and managerial considerations}

While this study formed a clearer definition of an ecologically sustainable campsite, successfully shifting use away from sensitive areas preferred by visitors may require additional management actions. For example, two studies indicate that proximity to water is an important campsite feature for visitors (Farrell et al., 2001; Lime, 1971). Locating or constructing sustainable campsites should also consider features or characteristics that attract visitor use or enhance desirability. Success in limiting the areal extent of impact at Michigan's Isle Royale National Park was partially attributed to managers actively creating and maintaining smooth, well-drained tent pads and providing visually obvious site boundary cues that encourage visitors to stay on-site (Farrell and Marion, 2002). To understand camping compliance, researchers in Virginia's Shenandoah National Park conducted interviews with visitors to inquire about their knowledge of camping policies and site selection (Reid and Marion, 2004). The most commonly cited characteristics of good campsites were bare ground (34\%), flat ground (18\%), fire rings
(16\%), and good tent sites (14\%). Knowing this, managers can "push" visitors away from unwanted campsites by re-naturalizing sites, removing fire rings, and ice-berging tent sites, and "pull" visitors to sustainable campsites by creating and maintaining smooth well-drained tent sites and anchoring small rock or steel fire rings (Marion et al., 2020b).

Success often requires long-term persistence in applying these "push-pull" efforts. The successful closure and restoration of campsites over the course of 32 years in Montana's Lee Metcalf Wilderness was attributed to persistent maintenance efforts to eliminate visual evidence of campsites and improving conditions on legal campsites (Cole, 2013). In Shenandoah National Park, persistent restoration and rehabilitation efforts, particularly after periods of peak use, were key to effectively reducing the areal extent of campsite impacts and implementation of a successful established site camping policy (Reid and Marion, 2004).

Management actions could also address impacts that are driven by visitor behavior, such as improperly disposed human waste, cutting of trees, and trash. Sites that are heavily impacted due to visitor behavior will require different actions to limit such behaviors (Monz and Twardock, 2010). For example, excessive tree damage and cutting can be addressed through education by asking visitors to leave woods tools at home and gather dead and downed wood that can be broken by hand. If subsequent monitoring reveals education to be ineffective then managers can justify prohibiting the use of woods tools for camping (Eagleston and Marion, 2017).

\subsection{Suggestions for future research}

A holistic view of campsite sustainability considers social and managerial aspects that this study did not investigate but that we suggest are important for future research. Knowledge of an ecologically sustainable site is only useful if managers can successfully move visitors to those sites; considering visitor campsite preferences when developing a campsite inventory is necessary to account for socially-defined visitor preferences. Other aspects of social sustainability could include the potential for user conflicts and safety-related concerns, the quality of visitors' experiences, and a visitor's ability to interpret and apply agency management guidance. Aspects of managerial sustainability include considerations of monetary, staffing, and maintenance capabilities, such as the ability to remove large hazardous trees.

This is the first study that has conducted comprehensive regression modeling with large numbers of variables to assess and document their relative influence on areal measures of camping impact. The study also incorporated extensive GIS analyses and utilized accurate LiDARderived topographic data to characterize the influence that topographic characteristics have on campsite impact. Future work should continue to refine, expand and calibrate these methods; seeking the optimal scale(s) for GIS-derived variables which may more accurately characterize their influence on campsite size. For example, LiDAR DEMs at $1 \mathrm{~m}$ resolution may be characterizing large slope values due to small changes in the terrain that may or may not influence camping decisions. Terrain roughness and topographic position indicators were developed in the literature using lower resolution DEMs and the published classification break points may not be calibrated for the spatial scale of a $1 \mathrm{~m}$ DEM. Work should be done to calibrate these indices for working with data at this smaller spatial scale and we suggest the inclusion of groundbased topography and rugosity ratings for comparison. Additionally, errors associated with either campsite location accuracy, campsite polygon accuracy or in the LiDAR data itself likely can have significant influence on the viability of these analyses. Additional research on the influence of facilities like shelters, huts, camping platforms, and side-hill campsites is needed. Finally, capturing amount of use data for primitive campsites remains a universal challenge, suggesting that more studies with experimental designs are needed. 


\section{Conclusion}

A cardinal rule of camping management is that managers should only shift use from less-to more-sustainable locations and only when they are confident that closure and recovery work will be successful at the original location (Cole, 2013; Cole et al., 1987). Restoration studies reveal that even low levels of camping use are sufficient to prevent recovery, so shifting use without recovery merely increases the aggregate area of camping impact (Cole et al., 2012). Advancing our knowledge of campsite sustainability is critical to enhancing managers' abilities to effectively evaluate and rate existing or potential new sites for sustainability, and to shift use from less to more sustainable campsites. Considering and integrating visitor campsite preferences to ensure ecologically sustainable sites appeal to visitors may also be key to successful sustainable campsite management that minimizes aggregate measures of campsite size and area of vegetation loss (Marion et al., 2020b).

This study increases our understanding of how environmental characteristics influence the areal extent of camping impact for a large representative sample of AT campsites. The relative influence of significant variables provides managers with the knowledge needed to improve selection, design, and management of campsites for sustainability. These results support indirect management methods that rely on the design and location of campsites in places that naturally resist proliferation and expansion impacts rather than actions that regulate behaviors that restrict visitor freedom. In response to rising visitation, the strategies and practices presented can aid in identifying and creating ecologically sustainable campsites. Proactive and focused camping management actions that manipulate influential factors are key to limiting visitor impacts and maintaining a sustainable inventory of campsites over time. However, while this research more fully describes the necessary elements required for sustainable camping management, we note that more research is needed to identify effective options for successfully shifting use to sustainable campsites.

\section{Credit author statement}

Johanna Arredondo: Methodology, Formal analysis, Writing - original draft, Writing - review \& editing, Visualization. Jeffrey Marion: Conceptualization, Methodology, Formal analysis, Writing - original draft, Writing - review \& editing, Visualization, Supervision, Project administration, Funding acquisition. Fletcher Meadema: Methodology, Formal analysis, Writing - review \& editing. Jeremy Wimpey: Conceptualization, Methodology, Formal analysis, Writing - review \& editing, Supervision, Funding acquisition.

\section{Funding}

This study was funded by the U.S. National Park Service, with guidance, collaboration, and contracting support provided by the Appalachian Trail Conservancy.

\section{Declaration of competing interest}

The authors declare that they have no known competing financial interests or personal relationships that could have appeared to influence the work reported in this paper.

\section{Acknowledgments}

We thank Chris Carr for collaboration and assistance in sampling, protocol development, and fieldwork, and Brian Peterson, Dylan Spencer, Kaitlin Burroughs, Mary-Ellen Burnette, and Mitch Rosen for their dedicated assistance collecting field data. Use of trade, product, or firm names is for descriptive purposes only and does not imply endorsement by the US Government.

\section{References}

Anselin, L., 1988a. Spatial econometrics: methods and models. In: Studies in Operational Regional Science, vol. 4. Springer Netherlands, Dordrecht.

Anselin, L., 1988b. Lagrange Multiplier test diagnostics for spatial dependence and spatial heterogeneity. Geogr. Anal. 20, 1-17.

Appalachian Trail Conservancy, 2009. Local Management Planning Guide. Harpers Ferry, WV.

Appalachian Trail Conservancy, 2018a. 2000 Milers. Harpers Ferry, WV. http://www. appalachiantrail.org/home/community/2000-milers. (Accessed 8 November 2018).

Appalachian Trail Conservancy, 2018b. Camping on the Appalachian Trail. Harpers Ferry, WV. http://www.appalachiantrail.org/home/explore-the-trail/thru-hiking/ camping. (Accessed 8 November 2018).

Appalachian Trail Conservancy, 2018c. Leave No Trace. Harpers Ferry, WV. http://app alachiantrail.org/home/explore-the-trail/leave-no-trace. (Accessed 8 November 2018).

Brown, J.A., Robertson, B.L., McDonald, T., 2015. Spatially balanced sampling: application to environmental surveys. Procedia Environmental Sciences 27, 6-9.

Brubaker, K.M., Myers, W.L., Drohan, P.J., Miller, D.A., Boyer, E.W., 2013. The Use of LiDAR terrain data in characterizing surface roughness and microtopography. Applied and Environmental Soil Science 13, 2013.

Cole, D.N., 1982a. Wilderness Campsite Impacts: Effect of Amount of Use. USDA Forest Service, Intermountain Research Station. Res. Pap. INT-284. Ogden, UT.

Cole, D.N., 1982b. Controlling the spread of campsites at popular wilderness destinations. J. Soil Water Conserv. 37, 291.

Cole, D.N., 1986. Ecological Changes on Campsites in the Eagle Cap Wilderness, 1979 to 1984. USDA Forest Service, Intermountain Research Station, Res. Pap. INT-368, Ogden, UT.

Cole, D.N., 1989. Area of Vegetation Loss: A New Index of Campsite Impact. USDA Forest Service, Intermountain Research Station, Res. Note INT-389. Ogden, OR.

Cole, D.N., 1992. Modeling wilderness campsites: factors that influence amount of impact. Environ. Manag. 16, 255-272.

Cole, D.N., 1993. Campsites in Three Western Wildernesses: Proliferation and Changes in Condition over 12 to 16 Years. USDA Forest Service, Intermountain Research Station, Res. Pap. INT-463. Ogden, UT.

Cole, D.N., 1995. Experimental trampling of vegetation. I. Relationship between trampling intensity and vegetation response. J. Appl. Ecol. 32, 203-214.

Cole, D.N., 2013. Changing Conditions on Wilderness Campsites: Seven Case Studies of Trends over 13 to 32 Years. USDA Forest Service, Rocky Mountain Research Station, Gen. Tech. Rep. RMRP-GTR-300. Fort Collins, CO.

Cole, D.N., Ferguson, T.E., 2009. A relatively nonrestrictive approach to reducing campsite impact: Caney Creek Wilderness, Arkansas. International Journal of Wilderness 15, 20-25.

Cole, D.N., Fichtler, R.K., 1983. Campsite impact on three western wilderness areas. Environ. Manag. 7, 275-288.

Cole, D.N., Hall, T.E., 1992. Trends in Campsite Condition: Eagle Cap Wilderness, Bob Marshall Wilderness, and Grand Canyon National Park. USDA Forest Service, Intermountain Research Station, Gen. Tech. Rep. RMRP-GTR-300, Ogden, UT.

Cole, D.N., Marion, J.L., 1988. Recreation impacts in some riparian forests of the Eastern United States. Environ. Manag. 12, 99-107.

Cole, D.N., Monz, C.A., 2003. Impacts of camping on vegetation: response and recovery following acute and chronic disturbance. Environ. Manag. 32, 693-705.

Cole, D.N., Monz, C.A., 2004. Spatial patterns of recreation impact on experimental campsites. J. Environ. Manag. 70, 73-84.

Cole, D.N., Parsons, D.J., 2013. Campsite Impact in the Wilderness of Sequoia and Kings Canyon National Parks: Thirty Years of Change. Natural Resource Tech. Rpt. NPS/ SEKI/NRTR—2013/665. National Park Service, Fort Collins, CO.

Cole, D.N., Dean, L., Taylor, D., Hall, T.E., 2012. Restoration of Plant Cover on Campsites in Subalpine Forests: Sawtooth Wilderness, Idaho. USDA Forest Service, Rocky Mountain Research Station, Res. Pap. RMRS-99. Fort Collins, CO.

Cole, D.N., Foti, P., Brown, M., 2008. Twenty years of change on campsites in the backcountry of grand canyon national park. Environ. Manag. 41, 959-970.

Cole, D.N., Petersen, M.E., Lucas, R.C., 1987. Managing Wilderness Recreation Use: Common Problems and Potential Solutions. USDA Forest Service, Intermountain Research Station, Gen. Tech. Rpt. INT-230. Ogden, UT.

Coombs, E.A.K., 1976. The Impacts of Camping on Vegetation in the Bighorn Crags, Idaho Primitive Area. University of Idaho, Master's Thesis, Moscow, ID.

D'Antonio, A., Monz, C., Newman, P., Lawson, S., Taff, D., 2013. Enhancing the utility of visitor impact assessment in parks and protected areas: a combined social-ecological approach. J. Environ. Manag. 124, 72-81.

Daniels, M.L., Marion, J.L., 2006. Visitor evaluations of management actions at a highly impacted Appalachian Trail camping area. Environ. Manag. 38, 1006-1019.

Dixon, G., 2017. A longitudinal study of backcountry track and campsite conditions on the Overland Track, Tasmania, Australia. Journal of Outdoor Recreation and Tourism 19, 25-36.

Dixon, G., Hawes, M., 2015. A longitudinal multi-method study of recreational impacts in the Arthur Range, Tasmania, Australia. Journal of Outdoor Recreation and Tourism 9, 64-76.

Eagleston, H., Marion, J.L., 2017. Sustainable campsite management in protected areas: a study of long-term ecological changes on campsites in the Boundary Waters Canoe Area Wilderness, Minnesota, USA. J. Nat. Conserv. 37, 73-82.

Eagleston, H.A., Marion, J.L., 2018. "Naturalness" in designated Wilderness: long-term changes in non-native plant dynamics on campsites, Boundary Waters, Minnesota. For. Sci. 64, 50-56.

Farrell, T., Hall, T.E., White, D.D., 2001. Wilderness campers' perception and evaluation of campsite impacts. J. Leisure Res. 33, 229. 
Golgher, A.B., Voss, P.R., 2016. How to interpret the coefficients of spatial models: spillovers, direct and indirect effects. Spatial Demography 4, 175-205.

Growcock, A.J., Pickering, C., 2011. A guilt-free roll in the grass: minimal short-term impacts from short-term camping in the Australian Alps. J. Ecotourism 10, 86-100.

Hammitt, W.E., Cole, D.N., Monz, C.A., 2015. Wildland Recreation: Ecology and Management. John Wiley \& Sons, NY.

Hill, R., Pickering, C., 2009. Differences in resistance of three subtropical vegetation types to experimental trampling. J. Environ. Manag. 90, 1305-1312.

Kangas, K., Sulkava, P., Koivuniemi, P., Tolvanen, A., Siikamaki, P., Norokorpi, Y., 2007. What determines the area of impact around campsites? A case study in Finnish national park. For. Snow Landsc. Res. 81, 139-150.

Leung, Y.-F., Marion, J.L., 1999. Characterizing backcountry camping impacts in Great Smoky Mountains national park, USA. J. Environ. Manag. 57, 193-203.

Leung, Y.-F., Marion, J.L., 2000a. Recreation impacts and management in wilderness: a state-of-knowledge review. In: Cole, D.N., et al. (Eds.), Proceedings: Wilderness Science in a Time of Change Conference, vol. 5. Wilderness ecosystems, threats, and management, pp. 23-48, 1999 May 23-27; USDA Forest Service, Rocky Mountain Research Station, Proceedings RMRS-P-15-VOL-5. Ogden, UT.

Leung, Y.-F., Marion, J.L., 2000b. Wilderness campsite conditions under an unregulated camping policy: an Eastern example. In: Cole, D.N., et al. (Eds.), Proceedings: Wilderness Science in a Time of Change, vol. 5. Wilderness ecosystems, threats, and management, Ogden, UT, pp. 148-152, 1999 May 23-27; USDA Forest Service, Rocky Mountain Research Station, Proceedings RMRS-P-15-Vol-5.

Leung, Y.-F., Marion, J.L., 2004. Managing impacts of camping. Book Chap. In: Buckley, R. (Ed.), Environmental Impacts of Ecotourism, pp. 245-258 (Wallingford, UK).

Leung, Y.-F., Spenceley, A., Hvenegaard, G., Buckley, R., 2018. Tourism and Visitor Managment in Protected Areas: Guidelines for Sustainability. IUCN. Best Practice Protected Area Guidelines Series, vol. 27. Gland, Switzerland.

Liddle, M.J., 1997. Recreation Ecology: the Ecological Impact of Outdoor Recreation and Ecotourism. Chapman \& Hall, NY.

Lime, D.W., 1971. Factors Influencing Campground Use in the Superior National Forest of Minnesota. USDA Forest Service, North Central Forest Experimental Station, Res. Pap. NC-60, St. Paul, MN.

Lindsay, J.B., Cockburn, J.M.H., Russell, H.A.J., 2015. An integral image approach to performing multi-scale topographic position analysis. Geomorphology 245, 51-61.

Manning, R.E., Valliere, W., Bacon, J.J., Graefe, A., Kyle, G., Hennessy, R., 2000. Use and users of the appalachian trail: a source book. In: National Park Service, Appalachian National Scenic Trail, Harpers Ferry, WV.

Marion, J.L., 1984. Ecological Changes Resulting from Recreational Use: A Study of Backcountry Campsites in the Boundary Waters Canoe Area Wilderness, Minnesota. Dissertation, University of Minnesota, St. Paul, MN.

Marion, J.L., 1995. Capabilities and management utility of recreation impact monitoring programs. Environ. Manag. 19, 763-771.

Marion, J.L., 2003. Camping Impact Management on the Appalachian National Scenic Trail. Appendix 2. Appalachian Trails Conference. Harpers Ferry, WV.

Marion, J.L., 2014. Leave No Trace in the Outdoors. Stackpole Books, Mechanicsburg, PA.

Marion, J.L., Farrell, T.A., 2002. Management practices that concentrate visitor activities: camping impact management at Isle Royale National Park, USA. J. Environ. Manag. 66, 201-212.

Marion, J.L., 2016. A review and synthesis of recreation ecology research supporting carrying capacity and visitor use management decision making. J. For. 114, 339-351.

Marion, J.L., Leung, Y.-F., 1997. An assessment of campsite conditions in Great Smoky Mountains national park. In: National Park Service, Great Smoky Mountains National Park, Research/Resources Mgmt. Rpt., Gatlinburg, TN.
Marion, J.L., Leung, Y.-F., 2004. Environmentally sustainable trail management. Book Chapter. In: Buckley, Ralf (Ed.), Environmental Impact of Tourism. CABI Publishing., Cambridge, MA, pp. 229-244.

Marion, J.L., Reid, S.E., 2007. Minimising visitor impacts to protected areas: the efficacy of low impact education programmes. J. Sustain. Tourism 15, 5-27.

Marion, J.L., Wimpey, J., 2017. Assessing the influence of sustainable trail design and maintenance on soil loss. Journal of Environmental Mgmt 189, 46-57.

Marion, J.L., Arredondo, J., Wimpey, J., Meadema, F., 2018a. Applying recreation ecology science to sustainably manage camping impacts: a classification of camping management strategies. International Journal of Wilderness 24, 84-100.

Marion, J.L., Leung, Y.-F., Eagleston, H., Burroughs, K., 2016. A review and synthesis of recreation ecology research findings on visitor impacts to wilderness and protected natural areas. J. For. 114, 352-352.

Marion, J.L., Wimpey, J., Arredondo, J., Meadema, F., 2020a. Improving the sustainability of the appalachian trail: trail and recreation site conditions and management. Final report to the. In: National Park Service, Appalachian Trail Park Office and the Appalachian Trail Conservancy. Harpers Ferry, WV, p. 137.

Marion, J.L., Wimpey, J., Arredondo, J., Meadema, F., 2020b. Sustainable camping "best management practices." DOI U.S. Geological survey, Virginia tech field unit. Final research report to the. In: National Park Service, Appalachian Trail Park Office, and the Appalachian Trail Conservancy. Harpers Ferry, WV, p. 57.

Marion, J.L., Wimpey, J., Lawhon, B., 2018b. Conflicting messages about camping near waterbodies in wilderness: a review of the scientific basis and need for flexibility. International Journal of Wilderness 24, 68-81.

Monz, C.A., Twardock, P., 2010. A classification of backcountry campsites in Prince William Sound, Alaska, USA. J. Environ. Manag. 91, 1566-1572.

National Park Service, 2008. Appalachian National Scenic Trail Resource Management Plan. Harpers Ferry, WV.

National Parks and Conservation Association, 2010. Appalachian National Scenic Trail: A Special Report. National Parks and Conservation Association, Washington, DC.

Reid, S.E., Marion, J.L., 2004. Effectiveness of a confinement strategy for reducing campsite impacts in Shenandoah National Park. Environ. Conserv. 31, 274-282.

Riley, S.J., DeGloria, S.D., Elliot, R., 1999. A terrain ruggedness index that quantifies topographic heterogeneity. Intermt. J. Sci. 5, 23-27.

Sharma, R.K., Bhatnagar, Y.V., Mishra, C., 2015. Does livestock benefit or harm snow leopards? Biol. Conserv. 190, 8-13.

Smith, A.J., Newsome, D., 2002. An integrated approach to assessing, managing and monitoring campsite impacts in Warren National Park, Western Australia. J. Sustain. Tourism 10, 343-359.

Spildie, D.R., Cole, D.N., Walker, S.C., 1999. Effectiveness of a confinement strategy in reducing pack stock impacts at campsites in the Selway-Bitterroot Wilderness, Idaho. In: Cole, D.N., et al. (Eds.), Proceedings: Wilderness Science in a Time of Change; Vol 5: Wilderness Ecosystems, Threats, and Management, pp. 199-208, 1999 May 23-27; USDA Forest Service, Rocky Mountain Research Station, Proceedings RMRS-P-15Vol-5. Ogden, UT.

Stevens, D.L., Olsen, A.R., 2004. Spatially balanced sampling of natural resources. J. Am. Stat. Assoc. 99, 262-278.

Tibshirani, R., 1996. Regression shrinkage and selection via the Lasso. J. Roy. Stat. Soc. B 58, 267-288.

Tien Bui, D., Nguyen, Q.P., Hoang, N.-D., Klempe, H., 2017. A novel fuzzy K-nearest neighbor inference model with differential evolution for spatial prediction of rainfall-induced shallow landslides in a tropical hilly area using GIS. Landslides 14, $1-17$.

Weiss, A., 2001. Topographic Position and Landforms Analysis, Poster Presentation. ESRI User Conference, San Diego, CA. 